\title{
DIREITO, LINGUAGEM E DEMOCRACIA
}

\author{
Jaqueline Mielke Silva* \\ André Karam Trindade
}

\begin{abstract}
Resumo: Partindo da obra 1984, de George Orwell, o presente artigo propõe uma reflexão crítica acerca das relações que se estabelecem entre direito, linguagem e democracia na pós-modernidade. Para tanto, apresenta a teoria do agir comunicativo, desenvolvida por Jürgen Habermas - com base na noção de razão comunicativa -, destacando o papel de integração social promovido pelo direito, cujas normas se legitimam em face do princípio da democracia.
\end{abstract}

Palavras-chave: direito; linguagem; democracia.

\begin{abstract}
Based on the 1984 book by George Orwell, this article proposes a critical reflection on the relations between law, language and democracy in post-modernity. It presents the theory of communicative action developed by Jürgen Habermas, based on the notion of communicative reason, highlighting the role of social integration promoted by the law, whose norms are legitimate in the face of the principle of democracy.
\end{abstract}

Keywords: law; language; democracy.

\section{O TOTALITARISMO NA OBRA 1984, DE GEORGE ORWELL}

Na obra $1984^{1}$, George Orwell retratou os males dos regimes totalitários e, de certo modo, sua desilusão com o comunismo. A figura do Estado, a manutenção do poder, a formação das ideologias, o papel da lei, o uso dos meios de comunicação, o sentido da guerra, a cultura do medo, o controle da linguagem, enfim, o império do autoritarismo. Estes são apenas alguns dos elementos presentes na obra-prima de George Orwell, escrita em 1948 e, posteriormente, adaptada para o cinema.

No romance distópico, o Partido Socialista Inglês é a razão última da existência e o agente coletivo do poder. Não se honra o país, a família, a religião; se vive e se honra somente o partido. O partido é eterno, onisciente, onipotente e onipresente. O Estado não permite pena de morte, mas estimula a morte maciça de crianças no abortamento. O Estado prega a igualdade de direitos, porém

\footnotetext{
* Doutora em Direito Público (UNISINOS). Professora de Direito Processual Civil do CESUCA. Professora da Escola de Direito da IMED. Advogada.

${ }^{* *}$ Doutor em Teoria e Filosofia do Direito (ROMA TRE). Professor de Direito Constitucional do CESUCA e da Escola de Direito da IMED. Coordenador do KATHÁRSIS - Centro de Estudos em Direito e Literatura da IMED. Produtor Executivo do Programa "Direito \& Literatura" (TV UNISINOS e TV JUSTIÇA).

${ }^{1}$ ORWELL, George. 1984. São Paulo: Companhia Editora Nacional, 2003.
} 
favorece, declaradamente, seus principais aliados. O Estado prega a distribuição de renda, mas, na verdade, acumula poder num partido que centraliza todas as ações.

Neste contexto, o protagonista Winston é um funcionário do famoso Ministério da Verdade, onde se encarrega de eliminar registros, documentos e quaisquer evidências que contradissessem as verdades proferidas pelo Grande Irmão. A ele cabia a tarefa de reescrever a história da nação de acordo com a doutrina do Partido. De um lado, as manchetes e notícias eram reeditadas através da manipulação dos fatos. Assim, com a reconstrução da História, a ideologia era conservada. De outro lado, as "inverdades" eram depositadas nos chamados "buracos da memória", onde eram incineradas.

Para tanto, Orwell apresenta a novilíngua, que amputa e reduz a linguagem; e a noção de duplipensamento, entendida como a capacidade de acreditar, simultaneamente, em duas crenças contraditórias. Na verdade, o que se verifica é a aniquilação da subjetividade em nome do coletivo, isto é, do Partido. Tudo isto porque, segundo o Grande Irmão, quem controla o passado, controla o futuro; e quem controla o presente, controla o passado.

Em suma, a obra de Orwell constitui um excelente pretexto para que se retome a discussão acerca do papel do Direito e da Democracia no atual paradigma do Estado Constitucional, tendo em vista a importância do estudo do discurso - jurídico e político - na construção da sociedade pósindustrial.

\section{A DEMOCRACIA E A NECESSIDADE DE ADEQUAÇÃO DO DIREITO NA PÓS-MODERNIDADE}

A maior dificuldade para a análise da democracia neste fim de século revela-se em razão do esgotamento das potencialidades críticas tanto do marxismo, quanto do liberalismo. Segundo Leonel Severo ROCHA, isto decorre epistemologicamente do paradoxal fato de que:

estas duas teorias antagônicas possuem perspectivas metodológicas positivistas, centradas na crença da objetividade da idéia de totalidade - axioma que permitiria a elaboração de teorias gerais, metalinguagens sintático-semânticas da política, explicativas de todos os fenômenos sociais².

Logo, percebe-se que marxistas e liberalistas são jogados em uma situação de indeterminação, frente a situações como a queda do muro de Berlim ou a destruição do império soviético, que não se encaixam na determinista ciência da história de Karl MARX ou no modelo que tudo prevê de Talcott PARSONS. A imprevisibilidade do acontecimento histórico que tudo prevê deixa em ruínas a ciência política objetivista ${ }^{3}$.

\footnotetext{
${ }^{2}$ ROCHA, Leonel S. Epistemologia jurídica e democracia. São Leopoldo: Unisinos, 1998, p. 173.

${ }^{3}$ Id., ibid., p. 173.
} 
A transformação do paradigma político dirige a uma (re)avaliação das relações entre o socialismo, o liberalismo e a democracia.

\title{
2.1 A crise da democracia
}

A concepção normativa de democracia entra em crise a partir do momento em que a confrontamos com a cultura pós-moderna. A crise da democracia é um resultado direto da crise da própria modernidade. É uma crise de alienação que nos faz pensar no novo amparado pelas sombras do velho.

A conciliação entre liberdade e igualdade é uma das grandes dificuldades clássicas da democracia. Pelo menos tradicionalmente, a igualdade sempre foi um dos princípios norteadores do socialismo; e a liberdade, do liberalismo. Na atualidade, em nível internacional, a discussão do pensamento liberal recuperou toda a sua importância com a sugestão de que o marxismo - centrado na defesa intransigente da igualdade, mas indiferente aos direito individuais e à liberdade - teria promovido a ascensão dos regimes totalitários ${ }^{4}$.

A respeito das relações entre democracia e totalitarismo, Alexis TOCQUEVILLE, ao tratar do sufrágio universal, refere ser o mesmo uma das condições para a existência de democracia nos Estados Unidos da América. Entretanto, percebe que o sufrágio universal poderia também, paradoxalmente, produzir um novo tipo de despotismo: a ditadura do número. Para ele, a maioria não tomaria sempre e necessariamente as melhores decisões. Do mesmo modo, teremos sempre minorias não representadas. Segundo o autor,

\begin{abstract}
Quando um homem ou um partido sofrem uma injustiça nos Estados Unidos, a quem você quer que ele se dirija? À opinião pública? É ela que constitui a maioria. Ao corpo legislativo? Ele representa a maioria e obedece-lhe cegamente. Ao poder executivo? Ele é nomeado pela maioria e lhe serve de instrumento passivo. À força pública? A força pública não passa da maioria sob as armas. Ao júri? O júri é a maioria investida do direito de pronunciar sentenças - os próprios juízes, em certos Estados, são eleitos pela maioria. Pois mais iníqua e insensata que sela a medida a atingi-lo, você tem de se submeter a ela ${ }^{5}$.
\end{abstract}

A igualdade de condições, para Alexis TOCQUEVILLE ${ }^{6}$ - indispensável para a democracia seria um perigo para a liberdade. Assim, a democracia poderia gerar dois tipos de problemas distintos e opostos: a tirania da maioria e o individualismo.

No entanto, Alexis TOCQUEVILLE ${ }^{7}$ percebeu igualmente que a democracia engendrava também, num mesmo movimento, as respostas aos seguintes problemas: descentralização

\footnotetext{
${ }^{4}$ Vejam-se as causas da "Perestroika" na União Soviética, na Polônia, Alemanha Oriental e Hungria, provocadas pela negação feita pelo marxismo aos direitos humanos mais elementares.

${ }^{5}$ TOCQUEVILLE, Alexis. A Democracia na América. São Paulo: Martins Fontes, 2001, p. 296.

${ }^{6}$ Id., ibid., p. 282 e ss.
} 
administrativa, equilíbrio dos poderes, plena autonomia do judiciário, organização federal, liberdade sindical, liberdade de imprensa, liberdade de associação, etc.

Pode-se dizer que, na atualidade, temos três principais correntes que procuram explicar o pensamento democrático: (a) democracia agregativa; (b) democracia deliberativa; (c) democracia radical.

A democracia agregativa possui como principal fonte de referência o modelo téorico encontrado na obra do economista austríaco Joseph A. SHUMPETER ${ }^{8}$. Na obra Capitalism, Socialism \& Democracy, são lançadas as bases de uma concepção de democracia que viria a influenciar todo o pensamento político no final do século $\mathrm{XX}^{9}$. A concepção de democracia exposta por Joseph A. SHUMPETER faz uma leitura da teoria weberiana, ressaltando o caráter instrumental da democracia. Essa perspectiva de democracia passou a ser dominante nos Estados Unidos, influenciando também a ciência política brasileira. Joseph A. SHUMPETER desenvolve um conceito empirista de poder, no qual o poder social se expressa na forma de interesses sociais relevantes que podem ser defendidos de modo mais ou menos racional. Segundo Patrícia Castro MATTOS:

\begin{abstract}
Sua teoria pluralista concebe o poder político como uma forma de poder social abstrato e duradouro, que permite intervenções no poder administrativo. Nessa perspectiva pluralista, o papel democrático se reduz essencialmente à escolha dos governantes, através do sufrágio universal. Shumpeter propõe o abandono de qualquer idéia de democracia como sendo a expressão dos anseios populares. Tal como Weber, a democracia, para ele, constitui apenas um instrumento mais eficaz de poder político. A dimensão simbólica da democracia é totalmente desprezada, classificando a política como um processo amoral. ... As decisões democráticas são, assim, o resultado da realização bem sucedida de idéias e coalizões por votos. O papel do cidadão, segundo esse modelo, se reduz ao de cliente do Estado, que paga impostos e em troca recebe serviços estatais ${ }^{10}$.
\end{abstract}

O modelo de democracia deliberativa, por sua vez, é o mais influente na discussão que vem sendo travada na filosofia política. Entre os representantes desse pensamento, destacam-se John RAWLS $^{11}$ e Jürgen HABERMAS ${ }^{12}$. Ambos partem de uma crítica ao modelo agregativo - centrado na idéia de interesses - e pretendem recuperar uma dimensão moral no âmbito da democracia liberal, sem a qual prevêem o seu fracasso. Para tanto, compartilham a premissa de que é possível obter um

\footnotetext{
${ }^{7}$ Id., ibid., p. 282 e ss.

${ }^{8}$ Ver SHUMPETER, Joseph A. Capitalism, socialism \& democracy. London: Routledge, 1996.

${ }^{9}$ Neste sentido: KOZICKI Kátia. Conflito e Estabilização: comprometendo radicalmente a aplicação do Direito com a democracia nas sociedades contemporâneas. Tese de Doutorado em Direito, Universidade Federal de Santa Catarina, 2000, p. 73.

${ }^{10}$ MATTOS, Patrícia Castro. As visões de Weber e Habermas sobre Direito e Política. Porto Alegre: SaFe, 2002, p. 122-123.

${ }^{11}$ RAWLS, John. A theory of justice. Cambridge, Massachusets: Harvard University Press, 1972.

${ }^{12}$ Cf. HABERMAS, Jürgen. Between facts and norms - contributions to a discourse theory of law and democracy. Cambridge: Mit Press, 1996.
} 
consenso moral puramente racional, o qual é mais do que simples concordância quanto a procedimentos $^{13}$. Ao tratar da democracia deliberativa, refere Patrícia Castro MATTOS:

Enquanto na democracia de interesses as pessoas não deixam seu ponto de vista subjetivo para adotar uma visão mais geral dos assuntos políticos, a democracia deliberativa, por sua vez, concebe a democracia como um processo que cria um público, cidadãos unidos para tratar de objetivos, ideais, ações e problemas coletivos. Os processos democráticos são baseados num diálogo livre e aberto, onde o que vale é a força do melhor argumento, tal como define Habermas ${ }^{14}$.

A teoria da democracia radical, por fim, parte da constatação de que a chamada revolução democrática constitui um marco na história do pensamento político e inicia um novo tempo para a chamada filosofia política. Chantal MOUFFE ${ }^{15}$ é uma das principais representantes dessa corrente de pensamento. A democracia radical pretende repensar a própria democracia liberal, no sentido de resgatar seus princípios políticos constitutivos - liberdade e igualdade - e analisar de que forma a mesma pode vir a fazer frente aos problemas que se colocam no presente. Segundo Kátia KOZICKI,

Esta matriz teórica não somente reconhece a existência do pluralismo, e a impossibilidade de que o mesmo possa ser eliminado, como acredita que o mesmo deve ser reconhecido como um valor em si mesmo. Reconhecendo a contingência, a indeterminação de sentido e a abertura como características marcantes das sociedades contemporâneas, a democracia radical recusa quaisquer concepções teóricas que tentem reduzir as identidades coletivas a uma base pré-determinada ou naturalista. Concebendo a identidade dos diversos atores e grupos sociais como sendo o resultado do entrelaçamento das várias posições de sujeitos que estes ocupam na sociedade, tal matriz aponta a importância do reconhecimento da diferença e da criação de identificações coletivas em torno de objetivos comuns, assumindo o conflito como inerradicável da arena política. Estas identificações, consubstanciadas na idéia da formação de uma lógica da equivalência das lutas democráticas, permitiriam a formação de laços de solidariedade social capazes de viabilizar a formação do consenso mínimo requerido pela vida em comunidade. Este consenso será sempre parcial e provisório, sujeito a novas articulações de sentido. É justamente nesta necessidade de fechamento que o papel do Direito se destaca, revelando a importância e necessidade de uma análise interdisciplinar ${ }^{16}$.

Em razão das deficiências dos pensamentos liberal e marxista perante a questão democrática, a concepção de democracia radical parece ser o melhor caminho para se formular novas condições de possibilidade para a compreensão da mesma ${ }^{17}$. Segundo Leonel Severo ROCHA, "precisa-se abandonar os arcaísmos do liberalismo e do marxismo (socialismo) para se verem discursos como práxis instituintes de nossas identificações" ${ }^{\text {"18. }}$.

\footnotetext{
${ }^{13}$ Cf. KOZICKI, op. cit., p. 74.

${ }^{14}$ MATTOS, op. cit., p. 125 .

${ }^{15}$ Cf. MOUFFE, Chantal. Dimensions of radical democracy - Pluralism, Citizenship, Community. London: Verso, 1992.

${ }^{16}$ Cf. KOZICKI, op. cit., p. 248.

${ }^{17}$ Cf. ROCHA, Epistemologia..., op. cit., p. 181.

${ }^{18}$ Id., ibid., p. 179.
} 
Indaga-se: como escapar do impasse colocado pela constatação de que existe, na democracia liberal, uma relação de dominação escamoteada pela ideologia, simultaneamente com a constatação de que a democracia socialista pode levar ao totalitarismo?

Leonel Severo ROCHA propõe - aproximando-se da tese da democracia radical - que

Tal abordagem deve ser então encarada como uma questão política, vendo a política como uma forma de sociedade que, enquanto auto-instituída historicamente, necessita de um novo paradigma cultural - ação comunicativa emancipatória - para sua plena valorização democrática ${ }^{19}$.

Registra, todavia, que uma dialética elementar entre o ser e o dever-ser do Direito (e a política), não é porém de fácil realização, pois

exige uma revolução epistemológica que permita a comunicação entre o eixo sincrônico e o eixo diacrônico da lingüística (Saussure), interrelacionando a língua e a fala: o sistema jurídico e a história. Para tanto, é preciso ter-se uma concepção semiótica (revista politicamente pela matriz Habermas-Lefort) fundada numa matriz discursiva centrada na enunciação, enquanto reflexão crítico-hermenêutica dos enunciados das normas jurídicas. Trata-se de uma crítica à técnica jurídicodogmática, voltada muito mais a um controle democrático de sua produção e de seus mecanismos procedimentais e decisórios do que uma pura negação irracionalista ou ideológica das regras do jogo ${ }^{20}$.

Observa-se, assim, que a democracia se caracteriza como uma prática política que produz o sentido de uma forma de sociedade, gerando espaços de resistência e alteração ao funcionamento do espaço social ${ }^{21}$.

Logo, não se pode deixar nas mãos daqueles que possuem a riqueza e o saber a possibilidade de definir o sentido da democracia, nem a democracia como sentido de uma forma de sociedade. É preciso compreender que os "donos do saber" e da riqueza conseguem produzir significações que servem para a conservação de seus privilégios ${ }^{22}$.

A democracia não pode ser concebida a partir de valores pré-concebidos que não aceitam a idéia de que a sociedade precisa estar exposta a uma indeterminação permanente, a conflitos de todas as espécies.

Como sentido de uma forma de sociedade política, a democracia caracteriza a sociedade como um conjunto de práticas organizadas, a partir de um imaginário social que aceita a pluralidade e heterogeneidade de manifestações, desejos e ações. Ela aceita a permanente interpretação crítica dos modos da instituição social e, principalmente, permite atribuir à divisão e ao conflito o caráter de elemento constitutivo da vida, da política e do Direito.

\footnotetext{
${ }^{19}$ Id., ibid., p. 182.

${ }^{20}$ Id., ibid., p. 182.

${ }^{21}$ Ver WARAT, Luís Alberto. Introdução Geral ao Direito. Porto Alegre: SaFe, 1995, v. 3, p. 98.

${ }^{22}$ Id., ibid., p. 99.
} 
Entretanto, para Claude LEFORT ${ }^{23}$, a democracia encontra-se comprometida com práticas e idéias que vão instituindo permanentemente novos valores, novas necessidades e novos antagonismos na sociedade.

Segundo Claude LEFORT ${ }^{24}$, uma ordem social democrática precisa, para funcionar, do advento de práticas e significações que, pela ação de múltiplas circunstâncias históricas, vão instituindo novas relações com o poder, a dominação e o sentido da autonomia do homem. Nesta direção, a democracia não se encontraria comprometida com a organização das instituições existentes, seja para criticá-las, reforçá-las ou simplesmente aperfeiçoá-las. A democracia, em sua acepção tradicional, é uma prática do poder instituinte da sociedade, um espaço onde o poder se legitima por estar vinculado permanentemente aos conflitos e antagonismos sociais. A sociedade vai sendo constituída na dimensão do conflito e por sua constante redefinição.

Para Luís Alberto WARAT, ${ }^{25}$ a superação da "crise da democracia" - vista como produção predominantemente simbólica - pode concretizar-se a partir do reconhecimento de uma relação diferente entre lei, saber e poder. Deste modo, poderia passar a existir, fora do poder instituído, um pólo alternativo do poder e do saber. A partir desse pólo, desenvolver-se-ia, autônoma e conflitivamente - em disjunção com qualquer tipo de certezas -, uma dinâmica dos direitos e uma dinâmica do conhecimento. Logo, as relações de poder não poderiam continuar sendo encaradas de forma petrificada, como se elas fossem efeitos necessários da "pessoa de um príncipe", de um órgão coletivo ou de uma instância que funciona acima da sociedade.

Todavia, mesmo diante das novas condições apresentadas pela pós-modernidade, podemos reinventar a democracia ${ }^{26}$ através de uma preocupação no sentido de (a) tentar subverter e impor cada vez mais novos limites à pragmática de nossa cultura instituída; e (b) estabelecer resistência à ordem social que nos governa, reivindicando a autonomia para todos os setores da vida social, lutando contra as atuais condições de produção alienada de nossa subjetividade.

É preciso romper limites. As velhas seguranças e as evidências estabelecidas por uma forma de pensamento começam a produzir perplexidades e angústias para articular um programa de transformação da sociedade. A democracia depende da realização de um desejo de inovação.

O futuro depende da "nova roupagem" que vai se dar aos sistemas ideológicos, rompendo-se com as ciências pseudo-objetivas e aceitando-se a democracia como produtora do inédito, como um trabalho aberto à razão, um trabalho de interrogação sobre a forma moderna de dominação.

\subsubsection{A democracia como possibilidade de produção de sentido}

\footnotetext{
${ }^{23}$ LEFORT, Claude. La invención democrática. Buenos Aires: Nueva Visión, 1988, p. 187.

${ }^{24}$ Id., ibid., p. 187 e ss.

${ }^{25}$ Cf. WARAT, Introdução..., op. cit., p. 109.

${ }^{26}$ Sobre o tema, consultar SANTOS, Boaventura de Souza. Reinventar a Democracia. 2. ed. Lisboa: Gradiva, 2002 .
} 
O Direito é constituído por uma pragmática formal que articula pressupostos dogmáticotecnológicos em relação a expectativas de direito e questões político-morais. Segundo Leonel Severo ROCHA $^{27}$, a crise das sociedades de capitalismo avançado ocorre, para Jürgen HABERMAS, quando os aspectos sistêmicos, no nosso caso a técnica dogmática, ao invés de interagir com a práxis conflitiva das pretensões do cotidiano, transforma-se numa ideologia de dominação que impede a democratização das falas plurais e indeterminadas.

A crise acima declinada é bastante grande na América Latina - atingindo o Brasil diretamente -, circunstância essa que gera uma enorme crise de legitimação, devido às disfunções procedimentais e sociais do Direito. Essa crise do Direito implica em uma crise de governabilidade, que traz algumas conseqüências: (a) decretação da irracionalidade da opinião pública; (b) incapacidade dos especialistas em operacionalizar a razão estratégica; (c) decretação da falência do direito e da própria democracia.

Segundo Leonel Severo ROCHA ${ }^{28}$, impõe-se na América Latina - sem lei! - uma revisão das dificuldades para a efetivação da razão instrumental, antes de se proceder à sua crítica - embora ela seja necessária em outro nível discursivo. Para o autor, deve partir-se dos seguintes pressupostos:

(1) Existe uma especificidade simbólica do Direito. Isto implica que o Direito não se restrinja à lei, nem se reduz a um reflexo do poder.

(2) A questão das relações entre a teoria e prática jurídica e a teoria e prática política só pode ser resolvida pela rediscussão da democracia.

(3) A democracia é, assim, simultaneamente uma questão teórica e prática, implicando uma profunda revisão conceitual e uma ação política.

(4) A compreensão da democracia depende da compreensão do totalitarismo e da problemática dos direitos humanos.

(5) A grande questão é, portanto, a construção de uma nova cultura política apta a tematizar, compreender e recolocar toda essa imensa gama de problemas.

Partindo-se do pressuposto de que a democracia pressupõe a abertura, o reconhecimento da contingência, a aceitação de que os sentidos são plurais, irredutíveis a uma possibilidade significativa, chega-se à conclusão inevitável de que, através dela, é possível a produção de sentido. Todavia, toda produção de sentido - que torne possível a coexistência democrática dos diferentes sujeitos envolvidos - será sempre provisória, sujeita a novas construções significativas e novas formas de articulação. Assim, é preciso reconhecer que toda tentativa de fixação de sentido será sempre parcial ${ }^{29}$.

\footnotetext{
${ }^{27}$ ROCHA, Epistemologia..., op. cit., p. 183.

${ }^{28}$ Id., ibid., p. 183.

${ }^{29}$ Cf. KOZICKI, op. cit., p. 205.
} 
Uma nova cultura política - articulada a partir da idéia de forma de sociedade - permitiria ver que o Direito não se esgota na dominação, sendo um dos fatores fundamentais para a Democracia ${ }^{30}$. Através da democracia, pode-se então dizer que o Direito interage com a prática cotidiana, produzindo sentido. É esta interação que Jürgen HABERMAS sustenta em sua Teoria da Ação Comunicativa, a seguir explicitada.

\section{DA RAZÃo PRÁTICA À RAZÃo COMUNICATIVA}

Niklas LUHMANN eliminou a razão prática através da autopoiese dos sistemas dirigidos auto-referencialmente. Segundo Leonel Severo ROCHA ${ }^{31}$, a teoria sistêmica luhmanniana pretende responder a questão da racionalidade pragmática do direito, desde a proposta da elaboração de uma teoria geral da ação jurídica, com base nas reeleituras de Max WEBER e Talcott PARSONS, privilegiando os procedimentos para a produção das decisões, e não o seu conteúdo. Refere, ainda, o autor que essa teoria "tem sofrido fortes contestações através das teses hermenêuticas, às quais nos filiamos, seja a nível jurídico por intermédio de Karl Larenz, seja a nível político-epistemológico por Habermas (com quem travou famosa polêmica)"32.

De outro lado, Jürgen HABERMAS lança mão de um caminho diferente: a teoria do agir comunicativo. Segundo ele,

os vestígios do normativismo do direito racional perdem-se, pois, no trilema: após a implosão da figura da razão prática pela filosofia do sujeito, não temos mais condições de fundamentar os seus conteúdos na teleologia da história, na constituição do homem ou no fundo casual de tradições bem sucedidas. Isso explica os atrativos da única opção que ainda parece estar aberta: a do desmentido intrépido da razão em geral nas formas dramáticas de uma crítica da razão pós-nietzscheana, ou à maneira sóbria do funcionalismo das ciências sociais, que neutraliza qualquer elemento de obrigatoriedade ou de significado na perspectiva dos participantes. Ora, todo pesquisador na área das ciências sociais que não desejar apostar tudo em algo contra-intuitivo não será atraído por tal solução ${ }^{33}$.

${ }^{30}$ ROCHA, Epistemologia..., op. cit., p. 183.

${ }^{31}$ ROCHA, Leonel Severo. A Teoria Jurídica no Final do Século: Forma de sociedade, cultura política e democracia. Revista Brasileira de Filosofia, v. XLI, Fasc. 172, p. 365-78, out./dez. 1993.

${ }^{32}$ Id., ibid., p. 365-378.

${ }^{33}$ HABERMAS, Jürgen. Direito e Democracia - entre facticidade e validade. Rio de Janeiro: Tempo Brasileiro, 1997, v. I, p. 19-20, onde o autor complementa: "ou seja, ele é obrigado a empreender idealizações, por exemplo, a atribuir significado idêntico a enunciados, a levantar uma pretensão de validade em relação aos proferimentos e a considerar os destinatários imputáveis, isto é, autônomos e verazes consigo mesmos e com os outros. E, ao fazer isso, o que age comunicativamente não se defronta com o 'ter que' prescritivo de uma regra de ação e, sim, como o 'ter que' de uma coerção transcedental fraca - derivado da validade deontológica de um mandamento moral, da validade axiológica de uma constelação de valores preferidos ou da eficácia empírica de uma regra técnica”. 
Joseph HEATH ${ }^{34}$, ao analisar o pensamento habermasiano, refere que JÜRGEN HABERMAS não rejeita a concepção instrumental da racionalidade. Todavia, a substitui por uma alternativa, a concepção "comunicativa". Neste contexto, ele toma como seu ponto de partida a suposição de que os agentes têm à sua disposição um conjunto de padrões diferentes, muitas vezes incomensuráveis, de seleção. A ação comunicativa passa a ser uma ação governada por um padrão particular, ao passo que a ação instrumental passará a ser uma ação governada por algum outro padrão. Desse modo, segundo ele, Jürgen HABERMAS não está comprometido com uma reivindicação sobre a qual os agentes, às vezes, não deliberam instrumentalmente. A sua reivindicação é simplesmente o fato de que os modelos instrumentais não dão um embasamento suficiente para uma teoria geral de ação racional.

A introdução do conceito de razão comunicativa é essencial para que Jürgen HABERMAS se afaste da posição frankfurtiana de descrédito da razão e possa manter viva a intenção original daquela escola de desenvolver uma teoria social crítica. Para poder livrar-se do pessimismo sem saída em que se lançou a Escola de Frankfurt, depois que associou à razão a dominação, sob a forma de uma razão instrumental - bem como salvaguardar a crença na razão e o otimismo em relação ao futuro do homem - teve que encontrar uma forma positiva de manifestação da razão: aquela que lhe permitisse trabalhar a favor do homem e não contra ele, possibilitando-lhe evoluir, vencer obstáculos e formas de opressão $0^{35}$.

Em suma: Jürgen HABERMAS substitui a razão prática pela razão comunicativa ${ }^{36}$. O que torna possível a razão comunicativa é o meio lingüístico, através do qual as interações se interligam e as formas de vida se estruturam. Segundo ele,

Se pudermos pressupor por um momento o modelo da ação orientada ao entendimento, que desenvolvi em um outro estudo, deixa de ser privilegiada aquela atitude objetivamente em que o sujeito cognoscente se dirige a si mesmo como a entidades do mundo. Ao contrário, no paradigma do entendimento recíproco, é fundamental a atitude performativa dos participantes da interação que coordenam seus planos de ação ao se entenderem entre si sobre algo no mundo ${ }^{37}$.

A teoria do agir comunicativo não é uma fonte de norma do agir (ao contrário da figura clássica da razão prática). Ela possui um conteúdo normativo, porém somente na medida em que o que

\footnotetext{
34 "Habermas does not reject the instrumental conception of rationality and replaces it with an alternative, 'communicative' conception. Instead, he takes as his point of departure the assumption that agents always have available to them a set of different, often incommensurable standards of choice. Communicative action will turn out to be action governed by a particular standard, while instrumental action will be action governed by another. Thus Habermas is not comitted to be claim that agents do not sometimes deliberate instrumentally; his claim is simply that instrumental models do not provide a sufficient basis for a general theory of rational action" (HEATH, Joseph. Communicative Action and Rational Choice. Cambridge: Mit Press, p. 13).

${ }^{35}$ ARAGÃO, Lúcia Maria de Carvalho. Razão comunicativa e Teoria social crítica em Jürgen Habermas. Rio de Janeiro: Tempo Brasileiro, 1997, p. 61-64.

${ }^{36}$ HABERMAS elenca outras três raízes da racionalidade, além da comunicativa: racionalidade discursiva e reflexão, a racionalidade epistemológica e a racionalidade teleológica.

${ }^{37}$ HABERMAS, Jürgen. O Discurso Filosófico da Modernidade. Uma outra via para sair da filosofia do sujeito - Razão comunicativa vs. Razão centrada no sujeito. São Paulo: Martins Fontes, 2002, p. 416.
} 
age comunicativamente é obrigado a apoiar-se em pressupostos pragmáticos de tipo contrafatual. Segundo Joseph HEALTH,

Habermas crê que a ação comunicativa represente a ponta mais afastada de um processo de desenvolvimento no qual as formas complexas da ação social deram origem a aptidões que, por sua vez, permitiram o aparecimento de formas de ação mais sofisticadas. Pela visão de Habermas, o desenvolvimento da habilidade para envolver-se com ações comunicativas inicia com o surgimento daquilo que ele chama simbolicamente de interação mediadora ${ }^{38}$.

Jürgen HABERMAS ${ }^{39}$ rejeita a análise do conhecimento e da ação como meios adequados de refletir sobre a razão, tendo em vista que propiciaram uma visão unilateral da razão. Por isso é que ele postula a adoção da linguagem como um novo paradigma para a filosofia. Através da análise lingüística, ele acredita poder formular um conceito mais amplo de razão. Para Joseph HEATH,

\begin{abstract}
esse modo de interpretar o projeto de Habermas poria a teoria da decisão em seu devido lugar, anuindo que ficasse estipulado como adequada a caracterização da decisão racional nos contextos não-sociais. A ação comunicativa apresentar-se-ia em contextos sociais especificamente, porque a introdução das convicções no ambiente dos agentes apresenta um novo conjunto de variáveis que não podem ser diretamente manipuladas através da intervenção causal. O raciocínio lógico básico de Habermas no sentido de introduzir a ação comunicativa como um segundo tipo de ação racional tem, portanto, bastante fundamento, mesmo que o argumento que ele apresenta para motivar esta posição torne-se insuficiente para estabelecer sua necessidade. Tanto quanto diga respeito ao modelo instrumental de racionalidade, o fato de os agentes estarem em condições de se comunicarem com sucesso é um grande mistério. Isso significa que qualquer tentativa para ampliar a ação racional da noção para justificar a comunicação, inicia com uma certa plausibilidade prima facie $^{40}$.
\end{abstract}

Prosseguindo-se no estudo do pensamento de Jürgen HABERMAS, imperioso salientar a tensão entre a faticidade e a validade no interior da linguagem.

\footnotetext{
38 "Habermas believes that communicative action represents the tail end of a developmental process in which complex forms of social action have given rise to competencies that have in turn permitted the emergence of more sophisticated forms of action. In Haberma's view, the development of the capacity to engage in communicative actions begins with the emergence of what he calls symbolically mediated interaction" (HEATH, op. cit., p. 35).

${ }^{39}$ Cf. ARAGÃO, op. cit., p. 25.

${ }^{40}$ Segundo Joseph HEATH, "this way of construing Habermas's project would leave decision theory in place, granting that it provides as adequate characterization of rational decision in nonsocial contexts. Communicative action would arise in specifically social contexts, because the introduccion of beliefs into the agent's environment presents a new set of variables that cannot be directly manipulated through causal intervention. Habermas's basic rationale for introducing communicative action as a second type of rational action is therefore introducing communicative action as a second type of rational action is therefore quite sound, even though the argument that he presents to motivate this position falls short of establishing its necessary. As far as the instrumental model of rationality is concerned, the fact that agents are able to communicate successfully is completely mysterious. This means that any attempt to expand the notion rational action to account for communication starts out with a certain prima facie plausibility" (HEATH, op. cit., p. 25).
} 


\subsection{A tensão entre a faticidade e a validade no interior da linguagem}

Entre o estudo da razão, através da análise do conhecimento e da ação, e o mesmo estudo através da análise da linguagem ${ }^{41}$, não existem apenas diferenças de conteúdo e de método ${ }^{42}$, mas também em relação à própria dimensão da razão ${ }^{43}$. A razão que se depreende da atividade do sujeito cognoscente e agente ele caracteriza como subjetiva e instrumental, porque centrada na noção de subjetividade e voltada para o domínio teórico e/ou prático dos objetos. Hanna Fenichel PITKIN, ao tratar do pensamento de WITTGENSTEIN - um dos mais importantes autores que aborda o tema "linguagem"-, refere:

o que Wittgenstein sugere para substituir o enganoso quadro de linguagem que encontra em Santo Agostinho ou, ainda, como uma primeira etapa para conseguir uma perspectiva diferente e melhor, é uma concepção da linguagem como atividade. Seguindo formas e níveis muito diferentes, pesquisa a idéia que a linguagem fundamenta-se em um discurso no qual se fala e se responde e que estas são coisas que nós fazemos. A linguagem é, primeiro que nada, o discurso e 'falar uma linguagem é parte de uma atividade ou forma de vida'. Neste sentido, 'as palavras são também fatos'. Desta forma, não se trata de que, ao compreender uma linguagem, capta-se algum tipo de essência interior do significado, pelo contrário, trata-se de saber como fazer certas coisas. "Compreender uma linguagem significa dominar uma técnica. Nesta atividade, nesta técnica, são as palavras as que são utilizadas, portanto 'a linguagem é um instrumento. Seus conceitos são instrumentos". Refere Wittgenstein: "A gente pode se perguntar: quando e para que falo isto? Que tipo de ações acompanham estas palavras? (Vamos pensar nos cumprimentos). Em que momentos usaremos estas palavras e para que?" Em resumo, Wittgenstein incorpora e pesquisa esta compreensão pragmática da

\footnotetext{
${ }^{41}$ A respeito do tema linguagem, ver: Richard RORTY (El giro lingüistico. Barcelona: Paidós Ibérica, 1998); John L Austin (Cómo hacer cosas con palabras.Barcelona: Paidós, 1998); Hanna Fenichel Pitkin (Wittgenstein: El lenguage, la politica y la justicia - Sobre el significado de Ludwig Wittgenstein para el pensamiento social y político. Madrid: Centro de Estudios Constitucionales, 1984); Genaro Carrió (Algunas palavras sobre las palavras de la ley. Buenos Aires: Abeledo Perrot, 1971); Genaro Carrió (Notas sobre Derecho y lenguage. 4. ed. Buenos Aires: Albeledo-Perrot, 1990).

${ }^{42}$ Cf. OLIVEIRA, Ana Claudia de; LANDOWSKI, Eric (Eds.). Do inteligivel ao sensivel - Em torno da obra de Algirdas Julien Greimas. São Paulo: EDUC, 1995, p. 116: "enquanto a lingüística stricto sensu prossegue eficazmente a sua vida sob impulso tradicional (os trabalhos de carácter descritivo ligados à ernologia, os desenvolvimentos impressionantes através da fonética acústica atinentes à tecnologia,a abertura para a semântica das línguas naturais, etc.), novo campos de investigação e de reflexão se desenvolvem, apoiando-se em parte nela: trata-se da semiótica (ou semiologia) que se constrói nos anos 60 e, um pouco mais tarde, da pragmática, a primeira considerada como um alargamento do conceito de linguagem ao conjunto dos sistemas de significação, verbais ou não-verbais, a Segunda, como uma exploração necessária dos restos da semiótica, no sentido que lhe dava a Escola de Viena (Carnap), quer dizer, como a projeção da forma sintáctica (= lógica) sobre as diversas semânticas (= ciências constituídas). Foi a extensão desses pontos de vista para além dos limites da lingüística propriamente dita e a constituição um pouco desordenada de novas disciplinas que justificaram a introdução da expressão ciências da linguagem que as engloba todas".

${ }_{43}$ "We have seen that Habermas focuses on language as a medium for coordinating action that is, for producing subsequent patterns of interaction. Action, however, can be coordinated in more than one way. So the central question is how precisely Habermas sees coordination coming out. The kind he is interested in occurs, as we have seen, only when actors are oriented 'to reaching an understanding. It is this orientation which constitutes the category 'communicative action'. The best way to get some initial illumination of what is intended by this notion is to contrast it with other competing notions of action." (WHITE, Stephen K. The recent work of Jürgen Habermas - Reason, justice \& modernity. New York: Cambridge University Press, 1988, p. 36.
} 
linguagem em duas grandes analogias: a comparação entre palavras e ferramentas e entre palavras e as peças, fichas ou indicadores de um jogo ${ }^{44}$.

A razão que pode ser descoberta pela análise da atividade dos sujeitos lingüísticos é uma razão intersubjetiva $^{45}$ (comunicativa), e não instrumental, porque a prática lingüística envolve pelo menos dois participantes (ou sujeitos) e tem como único objetivo o entendimento ${ }^{46}$. Jürgen HABERMAS julga poder concluir que a linguagem permite descobrir, em sua própria estrutura, estruturas de racionalidade heterogêneas à razão instrumental ${ }^{47}$.

Jürgen HABERMAS, ao tratar da transição do paradigma da consciência para o paradigma da linguagem, atribuiu relevante importância a Ludwig WITTGENSTEIN. Segundo Jürgen HABERMAS $^{48}$, as formas de vida de Ludwig WITTGENSTEIN - que correspondem aos mundos da vida de HUSSERL - já não obedecem às regras de síntese de uma consciência geral, mas às regras da gramática dos jogos de linguagem.

A filosofia lingüística já não entende como a fenomenologia, a conexão entre intenção e ação a partir de uma constituição de rede de sentido, isto é, no marco transcedental de um mundo que se constrói a partir de atos da consciência. O entrelaçamento de intenções já não se explica por uma gênese transcedental do sentido, mas mediante uma análise lógica do significado lingüístico. As regras transcedentais, conforme as que se estruturam os mundos da vida, resultam agora acessíveis - em termos de análise da linguagem - nas regras dos processos de comunicação.

\footnotetext{
${ }^{44}$ Hanna Fenichel PITKIN (op. cit., p. 62-63), ao tratar do pensamento de WITTGENSTEIN sobre a linguagem, refere: "lo que Wittgenstein sugiere para sustituir el engañoso cuadro del lenguage que encuentra en San Agustín, o al menos como una primera etapa para conseguir una perspectiva diferente y mejor, es una concepción del lenguage como atividad. Siguiendo formas y niveles mui diferentes, investiga sobre la idea de que el lenguage se fundamenta en un discurso en el que se habla y se responde y que éstas son cosas que nosotros hacemos. El lenguage es ante todo o discurso, y 'el hablar un lenguaje es parte de una atividad o de una forma de vida'. En este sentido, 'las palabras son también hechos'. De esta forma, no se trata de cuando se comprende un lenguage se capte alguna suerte de esencia interior del significado; antes al contrario, se trata de saber cómo hacer ciertas cosas. 'Compreender un lenguage significa dominar una técnica. En esta actividad, en esta técnica, son las palabras las que se utilizan, de tal forma que 'el lenguage es un instrumento. Sus conceptos son instrumentos'. Dice Wittgenstein: 'Uno puede preguntarse a sí mismo: ? cuándo y para qué digo esto? Qué clase de acciones acompañan a estas palabras? (Pensemos en cuando se hace un saludo.) ? En qué momentos utilizaremos estas palabras y para qué?. Concretamente, Wittgenstein incorpora e investiga esta comprensión pragmática del lenguage en dos grandes analogías: la comparación entre palabras y herramientas y entre palabras y las piezas, fichas o indicadores de un juego".

${ }^{45}$ Do ponto de vista da filosofia da linguagem, o autoconhecimento, característico da razão instrumental, sofre muitas críticas: "ele só é acessível intuitivamente, e o acesso a realidades da consciência é inevitavelmente introspectivo. Além disso, a descrição de entidades que surgem no interior do espaço de representação ou da corrente de vivências carrega consigo a mácula de parecer algo meramente subjetivo. Daí as críticas que a filosofia da linguagem lançou contra a filosofia da consciência. Ela renunciou ao acesso direto aos fenômenos da consciência e substituiu o autoconhecimento intuitivo, a reflexão ou a introspecção por procedimentos que não apelam para a intuição. Pelo contrário, partiu da análise de expressões lingüísticas para reconstruir racionalmente nosso conhecimento das regras gramaticais, baseada no fato de que a sentença de que nos utilizamos para transmitir um pensamento têm sua forma determinada por razões sintáticas" (ARAGÃO, op. cit., p. 27).

${ }^{46}$ Id., ibid., p. 25.

${ }^{47}$ Id., ibid., p. 25.

${ }^{48}$ HABERMAS, Jürgen. La Logica de las Ciencias Sociales. Madrid: Tecnos, 1988, p. 203.
} 
Nas pesquisas filosóficas, a linguagem é considerada por Ludwig WITTGENSTEIN ${ }^{49}$ a partir de uma perspectiva pragmática, como uma atividade social regida por regras, que se diversifica num conjunto plural e aberto de jogos lingüísticos. Na medida em que o significado das palavras depende das regras que regem seu uso dentro de um jogo de linguagem, a gramática é o marco de referência que decide quando é correta ou incorreta a prática lingüística.

Segundo Ludwig WITTGENSTEIN ${ }^{50}$, existe um conjunto de vivências e ações características dos seres humanos, cujos conceitos encontram-se naturalmente associados a certas expressões e reações corporais, que estão enraizadas num substrato de conduta pré-lingüístico, o qual é comum a todas a sociedades humanas (Exemplos de vivências e ações deste tipo são: falar, mandar, obedecer, sofrer, afligir-se, revoltar-se, temer, compadecer, etc.) Os jogos de linguagem que, nos diferentes idiomas, têm desenvolvido diversamente essas expressões primitivas não as substituem apenas por conduta verbal, porém as integraram como parte do significado das expressões lingüísticas relativas às referidas ações e vivência. O principal ponto da filosofia da linguagem de Ludwig WITTGENSTEIN, para Jürgen HABERMAS poder adequar a teoria do mundo da vida de HUSSERL ${ }^{51}$ à teoria da ação comunicativa, reside na relação posta por Ludwig WITTGENSTEIN entre o estabelecimento de regras de gramática de jogos de linguagem e formas de vida.

É possível modificar a teoria fenomenológica do mundo da vida e adequá-la à teoria da ação comunicativa na medida em que, ao transformar a relação intenção/ação numa relação

\footnotetext{
49 "En las Investigaciones Filosóficas el lenguage es considerado por Wittgenstein desde una perspectiva pragmática, como una actividad social regida por reglas, que se diversifica en un conjunto plural y abierto de juegos lingüísticos. En la medida en que el significado de las palabras depende de las reglas que rigen su uso dentro de un juego de lenguage, la gramática es el marco de referencia que decide cuando es correcta o incorrecta la práctica lingüística" (MARRADES MILLET, Julián. Gramática y naturaleza humana. In: VIDARTE, Vicente Sanfélix (Coord.). Acerca de Wittgenstein. Valencia: Universidad de Valencia, 1993, p. 97).

50 "Hay, según Wittgenstein, un conjunto de vivencias y acciones características de los seres humanos, cuyos conceptos se hallan naturalmente asociados a ciertas expresiones y reaciones corporales que están arraigadas en un sustrato conductual prelingüístico, el cual es común a todas las sociedades-humanas (ejemplos de vivencias y acciones de este tipo son: hablar, ordenar, obedecer, sufrir, afligirse, sublevarse, temer, esperar, compadecerse, etc). Los juegos de lenguage que, en las diferentes lenguas, han desarrollado diversamente esas expressiones primitivas, no las han suplantado sin más por conducta verbal, sino que las han integrado como parte del significado de las expresiones lingüísticas referentes a dichas acciones y vivencias" (id., ibid., p. 111).

51 "Husserl utilizara o conceito de mundo da vida como sinônimo de corrento da vida e de horizonte vivo da consciência que se reflete. Em A. Schültz e M. Heidegger o mundo da vida constituia um conjunto de referências do mundo cotidiano de atores sociais, as quais são dadas e experimentadas previamente. Ao passo que em Habermas o conceito mundo vital é delineado em traços mais amplos, abrangendo não somente o horizonte da consciência, mas também o contexto da comunicação lingüística, a praxis comunicativa do dia-a-dia, isto é, o contexto dos processos de comunicação voltada ao entendimento e ao consenso que é possível obter através da fala. $\mathrm{O}$ que equivale a dizer que o conceito de mundo vital passa a ser um conceito complementar ao conceito agir comunicativo. O 'mundo' do mundo da vida de Habermas não constitui, pois, o conjunto caótico das coisas no espaço e no tempo, como aparece na filosofia transcedental kantiana. Tampouco deve ser identificado com o complexo de funções do sistema social, como é apresentado na teoria do sistema de Niklas LUHMANN" (SIEBENEICHLER, Flávio Beno. Jürgen Habermas - Razão comunicativa e Emancipação. 2. ed. Rio de Janeiro: Tempo Brasileiro, 1990, p. 118).
} 
comunicação/ação, a noção de sentido deixa de ser concebida como um ato de consciência e passa a sê-lo como ato de comunicação, isto é, prática de entendimento ${ }^{52}$.

\title{
Segundo Jean GRONDIN,
}

\begin{abstract}
Contra o positivismo de uma sociologia aparentemente sem valor, que entende o agir social segundo o modelo de centros de força agindo atomística e causalmente uns sobre os outros, abstraindo, desta forma, totalmente do mundo da vida mediado pela linguagem dos agentes, Habermas vai em busca de uma fundamentação normativa e teórico-lingüística das ciências sociais. Esta recebeu a primeira ajuda no parto da teoria lingüística de Wittgenstein e da sua doutrina do jogo de linguagem, que corporifica simultaneamente uma forma de vida. Ele diagnosticou, todavia, um resto de positivismo na tese de Wittgenstein sobre o fechamento das formas de vida constituídas pela linguagem, como se cada agente estivesse monadicamente encerrado em seu mundo lingüístico. Para superar precisamente este limite, ele adotou o princípio hermenêutico. Habermas aprendeu de Gadamer, que a linguagem pode transcender-se a si própria, manifestando nisso o potencial de uma razão. A hermenêutica mostra que círculos lingüísticos não são fechados monadicamente, mas são porosos, tanto para fora como também para dentro, escreve Habermas. Para fora, porque a linguagem, em princípio, está aberta para tudo o que realmente se pode dizer e entender. Os seus horizontes ampliam-se constantemente. Mas também é aberta para dentro, pois os que agem pela linguagem podem distanciar-se de suas próprias expressões, para interpretá-las, refletir sobre elas, etc. A pretensão de universalidade da hermenêutica é, aqui, plenamente confirmada ${ }^{53}$.
\end{abstract}

Do ponto de vista pragmático, a linguagem assume relevância enquanto elemento mediador das relações que os falantes estabelecem entre si, quando se referem a algo no mundo. A partir dessa idéia, alargou-se o horizonte de análise da linguagem, passando-se a entendê-la como forma de comunicação $^{54}$. Ora, quando se usa sentenças, com uma intenção de comunicação, busca-se necessariamente alcançar o entendimento.

A teoria de Jürgen HABERMAS apresenta-se como uma tentativa de abarcar todas as manifestações racionais do sujeito, seja em suas ações diretas sobre o mundo nas suas mais variadas formas, seja nas expressões simbólicas que medeiam essas relações com o mundo. Qualquer ação pode ser tida por racional, desde que suscetível de criticismo e fundamentação, ou seja, desde que possa fornecer razões e fundamentos. Assim, o contraste entre uma forma de racionalidade cognitivoinstrumental e uma forma de racionalidade "comunicativa" - mais abrangente que a primeira ${ }^{-}$só aparece quando alguém se apega ao aspecto meramente descritivo do conhecimento, sem levar em

\footnotetext{
${ }^{52}$ Neste sentido, ver STIELTJES, Cláudio. Jürgen HABERMAS - A desconstrução de uma teoria. Jabaquara: Germinal, 2001, p. 261.

${ }^{53}$ GRONDIN, Jean. Introdução à Hermenêutica Filosófica. São Leopoldo: Unisinos, 1999, p. 215 e ss.

${ }^{54}$ Para demonstrar sua tese de que o modo original da linguagem é o uso comunicativo, Jürgen HABERMAS se utiliza da distinção de John L. AUSTIN entre atos ilocucionários e perlocucionários. Além dos atos locucionários, pelos quais o falante diz algo, expressa um estado de coisas; há os atos ilocucionários, pelos quais o falante realiza uma ação enquanto diz algo, e os atos perlocucionários, pelos quais o falante, ao falar, causa um efeito sobre o ouvinte, produz algo no mundo. Na distinção entre atos ilocucionários e perlocucionários, percebese a nítida distinção entre ações comunicativas e teleológicas. Nas últimas, o que é constitutivo para o ato da fala é a intenção do agente. Já nas primeiras, o que é constitutivo é o sentido do que é dito.
} 
conta todo o trabalho interpretativo que pode revelar a maior ou menor racionalidade das expressões ou ações, desde que apresentem justificativas "razoáveis".

A racionalidade de uma expressão é afirmada em função das relações internas entre o conteúdo semântico dessas expressões, suas condições de validade, e as razões - que podem ser fornecidas se necessário - para a verdade das afirmações ou a eficácia das ações. Conforme já mencionado, ela depende de ser suscetível de criticismo e fundamentação ${ }^{55}$.

Uma asserção pode ser dita racional somente se o falante satisfizer as condições necessárias para a meta ilocucionária de alcançar um entendimento sobre algo no mundo com pelo menos outro participante na comunicação. A racionalidade das expressões ou ações pode ser explicada mesmo que as duas tentativas falhem.

O conceito do agir comunicativo atribui às forças ilocucionárias da linguagem orientada ao entendimento a função importante de coordenação da ação ${ }^{56}$. De um lado, ele abrange todo o espectro de pretensões de validade da verdade proposicional, da veracidade subjetiva e da correção normativa, indo além do âmbito exclusivamente moral e prático. De outro lado, ela se refere apenas às intelecções e asserções criticáveis e abertas a um esclarecimento argumentativo, permanecendo neste sentido aquém de uma razão prática, que visa à motivação e à condução de vontade. A normatividade no sentido da orientação obrigatória do agir não coincide com a racionalidade do agir orientado pelo entendimento em seu todo. Normatividade e racionalidade cruzam-se no campo da fundamentação de intelecções morais, obtidas num enfoque hipotético, as quais detêm uma certa força de motivação racional, não sendo capazes, no entanto, de garantir por si mesmas a transposição de idéias para um agir motivado ${ }^{57}$.

A razão comunicativa, pois, possibilita uma orientação na base de pretensões de validade; no entanto, ela mesma não fornece nenhum tipo de indicação concreta para o desempenho de tarefas

\footnotetext{
${ }^{55}$ Segundo Jürgen HABERMAS, uma expressão satisfaz a pré-condição de racionalidade, se e na medida em que corporifica o conhecimento falível e, portanto, tem uma relação com o mundo objetivo - mundo dos fatos e está aberta ao julgamento objetivo (HABERMAS, Jürgen. The Theory of Communicative action. Boston: Beacon Press, 1984. v. I, p. 9).

${ }^{56}$ Genaro R. CARRIÓ (Notas sobre Derecho, op. cit., p. 19-20), ao tratar dos usos da linguagem, leciona: "se trata de una problemática que en muchos aspectos no ha sido aún suficientemente explorada. La lista parcial de actos que se pueden hacer con palabras, que nos demoró hace un momento, muestra, incluso a los ojos del menos alerta, la progidiosa riqueza y flexibilidad del lenguage. Este es una herramienta que sirve para los fines más variados. En un exceso de simplificación (o de dogmatismo) tratar todos esos usos o funciones del lenguage como si todos tuvieran (o tuvieran que tener) las mismas características. a). En ocasiones usamos el lenguage con un propósito primeordialmente descriptivo: para informar acerca de ciertos fenómenos o estado de cosas. b). Solemos valernos de ellas como vehículo o medio para expresar nuestros sentimientos, no en el sentido de describirlos, sino de exteriorizarlos; de darles, por decir así, salida o escape. c). otras veces nuestro propósito central al usar ciertas fórmulas verbales es dirigir el obrar de otras personas. Nos valemos del lenguage para inducir a otro a hacer tal o cual cosa, a comportarse de determinada manera. Se habla, por ello, de una función o uso directivo del lenguage. d). Se habla también de un uso 'operativo' (performative) del lenguage, que ofrece características muy especiales".

${ }^{57}$ HABERMAS, Direito e Democracia..., op. cit., p. 21.
} 
práticas, pois não é informativa, nem imediatamente prática. Ela tenta assimilar a tensão que existe entre faticidade e validade ${ }^{58}$.

O conceito de "agir comunicativo", que leva em conta o entendimento lingüístico como mecanismo de coordenação da ação, faz com que as suposições contrafatuais dos atores que orientam seu agir por pretensões de validade adquiram relevância imediata para a construção e manutenção de ordens sociais, pois estas mantêm-se no modo de reconhecimento de pretensões de validade normativas $^{59}$. Isso significa que a tensão entre faticidade e validade, embutida na linguagem e no uso da linguagem, retorna no modo de integração de indivíduos socializados - ao menos socializados comunicativamente - devendo ser trabalhada pelos participantes.

Tão logo as forças ilocucionárias das ações de fala assumem um papel de coordenador da ação, a própria linguagem passa a ser explorada como fonte primária de integração social. É nisso que consiste o agir comunicativo ${ }^{60}$. O mesmo refere-se ao uso da linguagem orientada pelo entendimento. Os participantes unem-se em torno da pretensa validade de suas ações de fala ou constatam dissensos, os quais eles, de comum acordo, levarão em conta no decorrer da ação.

\subsection{O processo de entendimento}

O processo de entendimento pode ser caracterizado pelas seguintes etapas ${ }^{61}$ :

para entender um ato-de-fala, o intérprete tem que estar familiarizado com suas condições de validade, tem que saber sob que condições a pretensão de validade ligada a ele é aceitável, isto é, teria que ser reconhecida pelo ouvinte; esse conhecimento das condições em que uma pretensão de validade pode ser aceita só pode ser obtido do contexto da comunicação observável: o intérprete observa sob que condições as expressões simbólicas são aceitas como válidas e quando são criticadas ou rejeitadas; ele nota quando os planos de ação dos participantes são coordenados através da formação de consenso e quando se desintegram devido à falta de consenso. Assim, o intérprete não pode esclarecer-se sobre o conteúdo semântico de uma expressão, independentemente de

\footnotetext{
${ }^{58}$ Ao tomar tal decisão, ela preserva - de um lado - "o engate na interpretação clássica de um nexo interno entre sociedade e razão, que pode ser mediado de diferentes maneiras, portanto um nexo entre circunscrições e coerções pelas quais transcorre a reprodução da vida social; de outro lado, ela não abandona a idéia de uma condução consciente da vida. E, ao optar por isso, envolve-se num problema: como explicar a possibilidade de reprodução da sociedade num solo tão frágil como o é das pretensões de validade transcendentes? O medium do direito apresenta-se como um candidato para tal explicação, especialmente na figura moderna do direito positivo. As normas desse direito possibilitam comunidades extremamente artificiais, mais precisamente, associações de membros livres e iguais, cuja coesão resulta simultaneamente da ameaça de sanções externas e da suposição de um acordo racionalmente motivado" (id., ibid., p. 25).

${ }^{59}$ Id., ibid., p. 35.

${ }^{60}$ HABERMAS, Direito e Democracia..., op. cit., p. 37.

${ }^{61}$ Id., The Theory of Communicative Action, op. cit., p. 115: e, ainda, ARAGÃO, op. cit., p. 40.
} 
contextos de ação em que os participantes reagem à expressão em questão com um 'sim' ou um "não" ou abstenção;

o intérprete não pode entender esse 'sim ou não', se não pode tornar claro para si as razões implícitas que levaram os participantes a assumirem tais posições; pois o acordo ou o desacordo, tanto quanto são julgados à luz de pretensões de validade reciprocamente erguidas e não meramente causadas por fatores externos, são baseados em razões que os participantes têm a seu dispor suposta ou realmente. Essas (na maioria das vezes implícitas) razões formam o eixo em volta do qual os processos de chegar a um entendimento revolvem; para trazer à mente as razões com que o falante deveria defender a validade de uma expressão, o próprio intérprete é arrastado para dentro do processo de afirmar pretensões de validade, pois, como refere Jürgen HABERMAS ${ }^{62}$, razões são de tal natureza que não podem ser descritas na atitude de uma terceira pessoa, isto é, sem reações de afirmação, negação ou abstenção. Por isso, para interpretar as expressões, o observador deve tomar uma posição em relação a elas; e não pode tomar essa posição, sem aplicar seus próprios padrões de julgamento, não solipsisticamente, mas relacionando-os criticamente com padrões de julgamento divergentes.

$\mathrm{Na}$ teoria da ação comunicativa, a concepção de uma idéia de sentido formado no ato de comunicação como prática do entendimento permite compreender não só por que as noções de sentido e de consenso estão associadas no mundo da vida da teoria da ação comunicativa, mas também por que o mundo da vida se torna um conceito complementar da ação comunicativa ${ }^{63}$. Segundo Flávio Beno SIEBENEICHLER,

A comunicação voltada para o consenso pode ser vista basicamente como uma troca ativa e pacífica de opinião e de informações entre participantes de uma determinada práxis social, portanto, como um processo social que se dá através da linguagem, tendo como referência certas estruturas de racionalidade. É o tipo de ação social orientada para o entendimento, a compreensão e o consenso, que se opõe à ação social orientada para o sucesso. É importante salientar a nota dinâmica do conceito de entendimento. Habermas não o define como sendo um consenso já obtido, mas como um processo comunicativo voltado para obtenção de um consenso ${ }^{64}$.

É preciso distingüir-se ainda dois níveis distintos para o entendimento: o dos participantes em interação, que estão lutando por uma interpretação sobre o qual pode haver um consenso, de modo a harmonizar seus próprios planos de ação com os outros atores; e daqueles que participam dos processos de alcançar entendimento com a finalidade pura e simples de compreender (o cientista social). Segundo Lúcia Maria de Carvalho ARAGÃO, o cientista social

\footnotetext{
${ }^{62}$ Id., ibid., p. 115.

${ }^{63}$ Cf. STIELTJES, op. cit., p. 262.

${ }^{64}$ Cf. SIEBENEICHLER, op. cit., p. 94.
} 
não participa dos sistemas de ação sob observação, não persegue metas relacionadas ao contexto dado, mas pertence a um outro sistema de ação, um segmento do sistema científico e, por este motivo, sua participação pode ser dita virtual. Essa sua participação virtual, entretanto, poderá influir na questão da objetividade das ciências sociais já que o cientista social não pode ganhar acesso a uma ralidade simbolicamente pré-estruturada apenas pela observação; e compreender o sentido não pode ser metodologicamente controlado, como a observação na experimentação. O cientista social já pertence, de certo modo, ao mundo-da-vida cujos elementos quer descrever. Para descrevê-los, deve entendê-los; para entendê-los, deve ser capaz de participar de sua produção. Isto proíbe o intérprete de separar questões de sentido de questões de validade, de modo a assegurar para a compreensão do sentido um caráter puramente descritivo ${ }^{65}$.

Alcançar entendimento é, pois, uma questão do conhecimento pré-teórico dos falantes competentes que sabem distinguir situações em que estão causalmente exercendo influência sobre outros daquelas em que estão chegando a um entendimento com os outros. Segundo Jürgen HABERMAS, entendimento seria um acordo alcançado comunicativamente ${ }^{66}$. Devido à sua estrutura lingüística, não pode ser meramente induzido pela influência externa ou pela força. Um acordo alcançado comunicativamente tem uma base racional; baseia-se em convicções comuns.

\subsubsection{A reconstrução das condiçães de integração social}

Os autores funcionalistas atribuem ao Direito a função de integração social ${ }^{67}$. O Direito contribui para se atingir o equilíbrio do sistema social, controlando, integrando ou arrefecendo os conflitos sociais e os desequilíbrios.

Segundo Talcott PARSONS ${ }^{68}$, o direito é um dos subsistemas sociais que, além de ter por função a integração social, realiza também a tarefa de gerar e exercer os meios de controle social pelos quais se comunicam aos usuários dos sistemas as regras de comportamento que devem ser seguidas. De acordo com a concepção funcionalista, o Direito constitui o meio mais eficaz de controle social. Talcott PARSONS, descreve a lei como

\footnotetext{
${ }^{65}$ Cf. ARAGÃO, op. cit., p. 41.

${ }^{66}$ HABERMAS, The Theory of Communicative Action, op. cit., p. 287.
}

${ }^{67}$ O Direito também pode servir para legitimar as decisões daqueles que têm a capacidade e o poder de tomá-las. A justificação, legitimidade, aceitação e consenso em torno dessas decisões são buscados através do Direito. Para Niklas LUHMANN, as regras jurídicas atribuindo competências e estabelecendo procedimentos para a tomada de decisão executam uma função de legitimação, em que o poder por elas intermediado transforma-se em direito. Segundo este mesmo autor: "d'altra parte, però, il diritto protrebbe servire anche a guidare il comportamento. Si promulgano leggi o si concludono contratti al fine di influenzare il comportamento di determinate persone e di dare ad esso un'altra direzione; e quindi, al fine di cambiare, per ciò che riguarda il futuro, probabilità di comportamento. Questa funzione non ha bisogno affato, o ha bisogno solo im modo molto formale, di riggersi sul passato. Essa si riferisce molto astrattamente a norme di competenza o a norme che conferiscono poteri per is resto segue una intenzione determinata solo rispetto alla situazione, segue uno scopo concreto che non ha bisogno di avere nessun passato" (LUHMANN, Niklas. Differenziazione del Sistema Giuridico - Contributi alla sociologia e alla teoria del diritto. Bologna: Il Mulino, 1990, p. 81).

${ }^{68}$ PARSONS Talcott. El Sistema de las Sociedades Modernas. México: Trillas, 1974 p. 29 e ss. 
um mecanismo generalizado do controle social. O Direito é um componente importante da estrutura social e reforça os valores, normas e regulamentos que constituem a organização da sociedade. A função fundamental da lei, segundo Parsons, é atenuar o conflito e incentivar, de modo mútuo e gradativo, o processo social em prol do diálogo social. As normas numa sociedade são intensificadas através da lei, muitas vezes pela utilização de várias sanções legais ${ }^{69}$.

Todavia, o controle social que o Direito exerce - para os funcionalistas - é bastante restrito: limita-se, sobretudo, à correção de "comportamentos desviados". A questão surge em se estabelecer o que é um "comportamento desviado".

André-Jean ARNAUD ${ }^{70}$ afirma ser possível assinalar dois grandes tipos de explicação do comportamento de desvio. A primeira maneira de explicá-lo é a partir da teoria da anomia de Émile DURKHEIM $^{71}$, que afirma referir-se o conceito de anomia a uma condição de relativa normalidade numa sociedade ou grupo. Émile DURKHEIM deixou claro que este conceito se referia a uma propriedade da estrutura social e cultural, e não a uma propriedade dos indivíduos que confrontavam tal estrutura. Não obstante, enquanto se tornava evidente e utilidade do conceito para entender diversas formas de comportamento desviado, ele foi se ampliando até referir-se a uma condição de indivíduos, em vez de se referir ao meio ambiente ${ }^{72}$. Segundo Alasdair MACINTYRE,

Durkheim, entretanto, forneceu uma pista para a procedência de ambos, quando descreveu, no final do século XIX, como o colapso das formas tradicionais de relação social aumentou a incidência de anomia, de falta de normas. Anomia, como Durkheim a caracterizou, era uma forma de privação, de perda da condição de membro das instituições e modos sociais, nos quais as normas estão expressas, incluindo as normas da racionalidade constituída pela tradição. O que Durkheim não previu foi uma época na qual a mesma condição de anomia receberia o estatuto de realização do eu e de recompensa para o eu que tivesse conseguido emancipar-se, separando-se, supostamente, das relações sociais das tradições ${ }^{73}$.

Ora, o tipo de controle social que exerce o Direito é coercitivo e a posteriori, pelo qual se permite a reafirmação dos valores protegidos pelos sistema, que são os que realmente mantêm a coesão e a ordem social.

\footnotetext{
69 "In his article "The Law and Social Control", Parsons ([1962] 1980) describes law as a generalized mechanism of social control. Law is an important component of the social structure and reinforces the values, norms, and rules that organize society. The primary function of law, according to Parsons, is to mitigate conflict and promote an integrative social process for social discourse. Through the law, the norms in a society are reinforced, often by the use of various legal sanctions" (GRANA, Sheryl J. et al. The social context of law. 2. ed. New Jersey: Prentice Hall, 2002).

${ }^{70}$ ARNAUD, André-Jean; DULCE, María José Fariñas. Introdução à Análise Sociológica dos Sistemas Jurídicos. Rio de Janeiro: Renovar, 2000, p. 146.

${ }^{71}$ DURKHEIM, Émile. A Divisão do Trabalho Social. 2. ed. São Paulo: Martins Fontes, 1999, p. 367 e ss.

${ }^{72}$ Neste sentido, ver MERTON, R. Social. Sociologia - Teoria e Estrutura. São Paulo: Mestre Jou, 1968, p. 235.

${ }^{73}$ MACINTYRE Alasdair. Justiça de quem? Qual Racionalidade?São Paulo: Loyola, 1991.
} 
Talcott PARSONS ${ }^{74}$ afirma que a função de integração e controle social começa com o processo de socialização, por meio do qual se transmite aos indivíduos as regras de conduta a serem seguidas no seu comportamento social. Os indivíduos delas se apoderam e as interiorizam. Quando há uma falha no processo de "socialização" - se os indivíduos não realizam o processo de interiorização e, conseqüentemente, não adaptam seu comportamento a normas - produz-se uma anomia ou desvio. É nessa segunda etapa que os mecanismos jurídico formais de controle social são postos em prática: "para corrigir ou atenuar os comportamentos desviados".

Robert K. MERTON ${ }^{75}$ afirma que o "desvio social" se produz como resultado de um "erro estrutural" ou de uma estruturação insuficiente das expectativas sociais. Para ele não se trata apenas de um erro no processo de socialização, mas o desvio também é conseqüência das características estruturais do sistema social. Essas características vêm com uma forte tensão ou, talvez, haja uma falta de correlação entre os objetos sociais, culturalmente definidos (riqueza, status social, sucesso profissional) e os meios legítimos pelos quais se pode atingir esses objetivos. O problema ou a tensão surge porque os objetivos também são definidos por todos os indivíduos, ao passo que os meios legítimos para atingi-los não estão igualmente ao alcance de todos, nem tampouco compartilhados por todos os indivíduos.

O “comportamento de desvio" aparece, então, como resposta do indivíduo a essa tensão, como resposta diante da má estruturação das expectativas sociais. Conseqüentemente, o "comportamento de desvio" não é excepcional, mas é uma situação permanente no sistema social, a qual resulta da ausência de correspondência entre os desejos sociais dos indivíduos e as possibilidades de que cada um dispõe para satisfazê-los. Segundo Robert K. MERTON,

\begin{abstract}
Uma freqüência crescente de comportamento desviado, mas 'bem sucedido', tende a diminuir e, até mesmo, como possibilidade extrema, a eliminar a legitimidade das normas institucionais para os demais componentes do sistema. O processo aumenta assim a extensão da anomia dentro do sistema, de modo que outros indivíduos que não reagiam sob forma de comportamento desviado à leve anomia que a prevalecia, chegam assim a proceder, quando a anomia se espalha e é assim especificada. Isto, por sua vez, cria uma situação mais agudamente anômica, para outros indivíduos do sistema social, que de início seriam menos vulneráveis ${ }^{76}$.
\end{abstract}

A segunda maneira de explicar o "comportamento de desvio" consiste em entender o desvio como sendo resultado de um processo social de rotulação ou de estigmatização social (labelling approch $^{77}$ ). Segundo as teorias do labelling approch, o desvio é uma resposta ao controle social. É justamente o controle social que desencadeia um "comportamento de desvio" e o marca como tal. A atenção já não é mais centrada no indivíduo e em seu comportamento, mas nos próprios órgãos de

\footnotetext{
${ }^{74}$ PARSONS, op. cit., p. 32 e ss.

${ }^{75}$ MERTON, , op. cit., p. 255 e ss.

${ }^{76}$ Id., ibid., p. 256.

${ }^{77}$ ARNAUD, op. cit., p. 147.
} 
controle social. Já não se considera, então, a norma para definir o que é um "comportamento de desvio", uma vez que ele surge como conseqüência de um processo de estigmatização realizado por órgãos encarregados de exercer o controle social (policiais, juízes, funcionários de penitenciárias, assistentes sociais). O "desvio social" é, portanto, resultado de um processo de reação social não neutro, que os diferentes órgãos jurídico-formais de controle social efetuam

Segundo André-Jean ARNAUD,

qualquer que seja a posição adotada para explicar a origem dos atos de desvio, é certo que o direito, ao ser considerado como um mecanismo de controle social, cumpre uma função de integração dos conflitos sociais e, conseqüentemente, também de manutenção da ordem de coesão social. O modo, porém, de exercer o controle social hoje mudou e, em conseqüência disso (...) a função de integração e de controle social do direito está em crise, ao menos tal qual foi caracterizada com base nas concepções do funcionalismo objetivista. O controle social que exerce o direito não deve sempre, nem necessariamente, ser repressivo, isto é, coercitivo a posteriori; ele deve até mesmo prevenir e promover. Ademais, por excessivo realce na função integradora e na de controle social do direito, tal como entendia o funcionalismo clássico, leva a ressaltar unilateralmente a tarefa do direito na atividade jurisdicional, e abandona-se o papel da legislação ${ }^{78}$.

Em que pese ser evidente a função de integração social que o direito possui, não se pode esquecer que o mundo da vida forma o horizonte para situações de fala e constitui, ao mesmo tempo, a fonte das interpretações, reproduzindo-se somente através de ações comunicativas ${ }^{79}$. Durante o agir comunicativo, o mundo da vida nos envolve no modo de uma certeza imediata, a partir da qual nós vivemos e falamos diretamente ${ }^{80}$.

A motivação racional para o acordo, que se apóia sobre o "poder dizer não", tem certamente a vantagem de uma estabilização não-violenta de expectativas de comportamento. Todavia, o alto risco de dissenso, alimentado a cada passo através de experiências, portanto através de contingências repletas de surpresas, tornaria a integração social, através do uso da linguagem, orientado pelo entendimento inteiramente implausível, se o agir comunicativo não estivesse embutido em contextos do mundo da vida ${ }^{81}$.

Jürgen HABERMAS assinala que:

se for verdade, como eu penso, seguindo Durkheim e Parsons, que complexos de interação não se estabilizam apenas através da influência recíproca de atores orientados pelo sucesso, então a sociedade tem que ser integrada, em última instância, através do agir comunicativo ${ }^{82}$.

\footnotetext{
${ }^{78}$ Id., ibid., p. 147.

${ }^{79}$ HABERMAS, Direito e Democracia..., op. cit., p. 41.

${ }^{80}$ Id., ibid., p. 41.

${ }^{81}$ Id., ibid., p. 40.

${ }^{82}$ Id., ibid., p. 45.
} 
Portanto, a integração social também é um elemento fundamental para Jürgen HABERMAS. E, desse modo, observa-se que tanto o direito quanto o agir comunicativo caracterizam-se como formas de integração social.

\subsubsection{Dimensões da validade do direito}

Quando o direito positivo sucedeu ao natural, momento em que todos os meios legítimos de usar a força passaram a ser monopolizados pelo Estado, esses direitos de usar a força transformaramse em autorizações para iniciar uma ação judicial ${ }^{83}$.

A validade do direito positivo é determinada pelo fato de que só vale como direito aquilo que obtém força de direito através de procedimentos juridicamente válidos - e que provisoriamente mantêm força de direito, apesar da possibilidade de derrogação dada pelo direito ${ }^{84}$. Todavia, esta validade do direito somente se explica através da referência simultânea à sua validade social ou fática e à sua validade ou legitimidade ${ }^{85}$.

Em geral, o sistema jurídico global possui um grau maior de legitimidade do que normas singulares ${ }^{86}$. A ordem jurídica deve tornar possível, a qualquer momento, a obediência de suas regras por obediência à lei ${ }^{87}$. Esta análise do modo de validade do direito obrigatório traz conseqüências para a normatização jurídica, pois revela que o direito objetivo tem que legitimar-se ${ }^{88}$.

Uma ordem jurídica não pode limitar-se apenas a garantir que toda pessoa seja reconhecida em seus direitos por todas as demais pessoas; o reconhecimento recíproco dos direitos de cada um por todos os outros deve apoiar-se, além disso, em leis legítimas que garantam, a cada um, liberdades iguais, de modo que a liberdade do arbítrio de cada um possa manter-se junto com a liberdade de todos. As leis morais preenchem esta condição; no caso das regras do direito positivo, no entanto, essa condição precisa ser preenchida pelo legislador político ${ }^{89}$.

No sistema jurídico, o processo de legislação constitui, pois, o lugar propriamente dito de integração social. Por isso, temos que supor que os participantes do processo de legislação saem do

${ }^{83}$ Id., ibid., p. 48.

${ }^{84}$ Ver HABERMAS, Jürgen. Sobre a legitimação pelos direitos humanos. In: MOREIRA, Luiz. Direito $e$ Legitimidade. São Paulo: Landy, 2003, p. 69.

${ }^{85}$ Ao contrário da validade convencional dos usos e costumes, o direito normatizado não se apóia sobre a faticidade de formas de vida consuetudinárias e tradicionais e, sim, sobre a faticidade artificial da ameaça de sanções definidas conforme o direito e que podem ser impostas pelo Tribunal (cf. HABERMAS, Direito $e$ Democracia..., op. cit., p. 50).

${ }^{86}$ HABERMAS, Direito e Democracia..., op. cit., p. 51.

${ }^{87}$ Segundo Henrique Cláudio de Lima VAZ, "o reconhecimento e o consenso encontram seu lugar como momentos dialéticos universais na idéia da comunidade ética e, ao alcançar sua expressão objetiva na Lei e no Direito, institucionalizam-se como formas universais do bem-comum. Na vida segundo a Lei e o Direito, definese, por sua vez, o perfil de uma consciência moral inter-subjetiva, que se manifesta eficazmente sobretudo quando alguma ameaça pesa sobre os fundamentos éticos da comunidade" (VAZ, Henrique Cláudio de Lima. Ética, Direito e justiça. In: MOREIRA, Luiz. Direito e Legitimidade. São Paulo: Landy, 2003, p. 126).

${ }^{88}$ HABERMAS, Direito e Democracia..., op. cit., p. 52.

${ }^{89}$ Id., ibid., p. 52-53. 
papel de sujeitos privados do direito e assumem, através de seu papel de cidadãos, a perspectiva de membros de uma comunidade jurídica livremente associada, na qual um acordo sobre os princípios normativos da regulamentação da convivência já está assegurado através da tradição ou pode ser conseguido através de um entendimento segundo regras reconhecidas normativamente ${ }^{90}$. Ao analisar o pensamento de Jürgen HABERMAS, refere Regenaldo da COSTA:

\begin{abstract}
Interessa, porém, para Habermas, explicar o surgimento da legitimidade a partir da legalidade, o que para ele se apresenta como um paradoxo devido, em parte, a essa compreensão subjetivista do direito. O paradoxo ocorre porque, por um lado, os direitos dos cidadãos têm a mesma estrutura de todos os direitos que abrem ao indivíduo esferas de liberdade de arbítrio e, por outro lado, o processo legislativo democrático precisa confrontar seus participantes com as expectativas normativas das orientações do bem comum da sociedade, na medida em que ele tem que extrair sua força legitimadora de um entendimento dos cidadãos sobre regras de sua convivência social ${ }^{11}$.
\end{abstract}

Assim, pode-se dizer que a transformação do direito operada por Jürgen HABERMAS resulta em três perspectivas ${ }^{92}$. A primeira, a constituição de uma normatividade diversa da razão prática, na medida em que a razão comunicativa se constitui como normatividade a posteriori. A segunda, não sendo imediata, mas apenas mediatamente normativa, validade inerente ao direito é falível, estando, portanto, sempre aberta à problematização e à revisão, tendo o direito que se instituir como disciplina prescritiva e, ao mesmo tempo, falível. A terceira, a rearticulação da relação entre direito e moral: há uma simultaneidade entre ambas as esferas, não havendo preponderância normativa de uma sobre a outra, ao mesmo tempo em que há uma relação de complementaridade operada por meio do processo legislativo.

\title{
3.3. O princípio da democracia e o controle da legitimação das normas
}

Jürgen HABERMAS ${ }^{93}$ indaga ainda: como seria possível fundamentar a legitimidade de normas que o legislador político pode modificar a qualquer momento? Segundo ele, a teoria política deu uma resposta dupla à questão da legitimidade através da soberania do povo e dos direitos humanos. Assim,

O princípio da soberania do povo e dos direitos humanos estabelece um procedimento que, a partir de suas características democráticas, fundamenta a suposição de resultados legítimos. Esse princípio expressa-se nos direitos à

\footnotetext{
${ }^{90}$ Id., ibid., p. 52-53.

${ }^{91}$ COSTA, Regenaldo da. Discurso, Direito e Democracia em Habermas. In: MOREIRA, Luiz. Direito e Legitimidade. São Paulo: Landy, 2003, p. 38.

${ }^{92}$ Neste sentido, ver MOREIRA, Luiz. Direito e Normatividade. In: MOREIRA, Luiz. Direito e Legitimidade. São Paulo: Landy, 2003, p. 151.

${ }^{93}$ Cf. HABERMAS, Sobre a legitimação pelos direitos humanos, op. cit., p. 69.
} 
comunicação e à participação que garantem a autonomia política dos cidadãos. Em contraposição a isso, aqueles direitos humanos clássicos que garantem aos membros da comunidade jurídica vida e liberdade privada para seguir os seus projetos pessoais, fundamentam uma soberania das leis que as torna legítimas a partir de si mesmas. Sob esses dois pontos de vista normativos, deverá legitimar-se o Direito codificado, portanto, modificável, como um meio de garantir uniformemente a autonomia privada e pública do indivíduo ${ }^{94}$.

O ideal político de governo pelo povo ou a idéia de que a lei deverá expressar a vontade do povo, que participa ativamente da formação de seu governo através do voto ou de outro modo, reside no ideal liberal, segundo o qual o processo político deve respeitar os cidadãos como pessoas autônomas, livres e iguais. Assim, o processo político deve ser estruturado de tal modo que respeite adequadamente a autonomia de cidadãos individuais. Se o processo for estruturado desta forma, podese considerar as decisões daí decorrentes um reflexo da vontade popular ${ }^{95}$.

Em determinados sistemas políticos - Alemanha e Estados Unidos, por exemplo -, há a previsão de uma instituição independente para examinar a constitucionalidade das leis emitidas pelo Congresso Nacional. Nesses países, desencadeia-se um debate entre a relação democracia e Estado de Direito e sobre a função e posição do Tribunal Constitucional de grande influência política.

Nos Estados Unidos, tem-se desenvolvido um grande debate sobre a legitimidade do controle das normas, exercido pela Suprema Corte $^{96}$, em última instância, pois a convicção republicana,

\footnotetext{
${ }^{94}$ Jean-François KERVÉGAN, ao tratar do tema, refere: "Minha tese é, portanto, dupla. Em primeiro lugar, a aceitação de uma ordem política democrática - a estrita igualdade dos direitos e dos deveres de cada indivíduo; o poder da coletividade de sobre si mesma e sobre seus membros - impõe que se renuncie a toda fundamentação metafísica, antropológica ou mesmo moral dos direitos do homem, e, antes de mais nada, daqueles que são fundamentais, em favor de uma fundamentação estritamente política, o seja, apoiada no único princípio de igualdade política (e não natural, pois nada é menos igualitário que a natureza) dos indivíduos-cidadãos. Os direitos do homem são, em outras palavras, os predicados da cidadania. Em segundo lugar, o princípio político da democracia exige que se ponha por terra a prioridade geralmente reconhecida à liberdade sobre a igualdade; nos próprios termos empregados por Rawls para caracterizar a "prioridade lexical da liberdade", isto significa que, numa perspectiva democrática conseqüente, a igualdade somente pode ser limitada em nome da própria igualdade. No meu modo de ver, esta é a única maneira coerente de honrar a exigência supra mencionada de uma definição política dos direitos do homem. Evidentemente, esta prioridade lexical não significa, em absoluto, que a liberdade seja secundária; mas ela é Segunda, na medida em que pressupõe a satisfação efetiva e integral do princípio da igualdade política e não pode, em nenhum caso, justificar um atenta contra este" (KERVÉGAN, Jean- François. Democracia e Direitos Humanos. In: MOREIRA, Luiz. Direito e Legitimidade. São Paulo: Landy, 2003, p. 123).

${ }^{95}$ Neste sentido, ver RICHARDSON, Henry. Em defesa de uma democracia qualificada. In: MOREIRA, Luiz. Direito e Legitimidade. São Paulo: Landy, 2003, p. 175.

${ }^{96}$ Sobre o tema, ver NOWAK, John E.; ROTUNDA, Ronald D. Constitutional Law. 5. ed. St Paul: West Publishing Co., 1995; CANON, Bradley C.; JOHNSON, Charles A. Judicial Policies. 2. ed. Washington: CQ Press, 1999; ROSENBERG, Gerald N. The Hollow hope - Can Courts bring about social change? Chicago/London: University of Chicago, 1991; TRIBE, Laurence H. American Constitucional Law. 3. ed. New York: Fondation Press, 2000. v. 1; TRIBE, Laurence H.; DORE, Michel C. On reading the Constitution. Cambridge/London: Harvard University Press, 1991; SCALA, Antonin et al. A Matter of Interpretation Federal Courts and the Law. Princeton: Princeton University Press, 1997; PERRY Jr., H. W. Deciding to decide - Agenda Setting in the United States Supreme Court. Cambridge/London, 1991; HORWITZ, Morton J. The Transformation of American Law 1870 - 1960 - The Crisis of Legal Orthodoxy. New York: Oxford University Press, 1992; LENOBLE, Jacques. La Procéduralisation Contextuelle du Droit. In: COPPENS, Philippe; LENOBLE, Jacques (Eds.). Démocratie et Procéduralisation du Droit. Bruxelas: Bruylant Bruxeles, 2000.
} 
segundo a qual "todo o poder do Estado vem do povo" recusa-se a aceitar o poder elitista de especialistas em direito que, apelando somente para a sua competência específica de interpretar a Constituição e sem serem legitimados pelas maiorias democráticas, revogam decisões de um legislativo eleito democraticamente ${ }^{97}$.

Frank MICHELMAN ${ }^{98}$ pensa que essa problemática está personificada em William J. BRENNAN. Ele descreve BRENNAN, de um lado, como um liberal que defende direitos de liberdade individuais, numa versão fortemente moral, e, de outro, como um democrata que radicaliza os direitos de participação e de comunicação, com a intenção de dar chances tanto aos silenciados e marginalizados, como é o caso dos opositores e dos que têm um comportamento desviante. Frank MICHELMAN $^{99}$ apresenta BRENNAN nas cores do pragmatismo americano e como modelo de um republicanismo atual, a fim de agudizar uma questão bastante relevante: será que uma sentença proferida por um juiz constitucional da República Federal, intervencionista e democrata convicto, que usa o instrumento pretensamente democrático do controle de norma, não é capaz de explicar a relação entre o princípio da soberania do povo e do Estado de direito?

Segundo Frank MICHELMAN ${ }^{100}$, BRENNAN visualiza o papel de um juiz responsável, que se qualifica como um intérprete democraticamente insuspeito da constituição, uma vez que a sua sentença só pode ser prolatada (segundo o melhor saber e a melhor consciência) após ter-se exposto, de modo paciente, curiosos, hermeneuticamente sensíveis e desejosos de aprender, à confusão das vozes dos discursos levados a cabo na sociedade civil e no espaço público, pois a interação com o grande público, perante o qual o jurista se sabe responsável, deve contribuir para a legitimação democrática do juízo de um juiz não suficientemente legitimado do ponto de vista democrático: é uma questão de maior ou menor confiança e de saber o que podemos fazer para apoiar isso. E uma condição que pode contribuir muito para a confiança é a exposição constante do intérprete - o leitor moral - para que haja a eclosão completa da variedade de opiniões sobre questões da correção de uma ou de outra interpretação produzida, livre e desinibidamente, por membros variados da sociedade, que auscultam o que os outros têm a dizer sobre suas diferentes histórias de vida, situações correntes e percepções de interesses e necessidades. Frank MICHELMAN, ao tratar do tema, refere ainda que

Isto não quer dizer que abandonamos o controle jurisdicional. Isto significa, antes, que reconstruímos o controle jurisdicional de tal maneira que o poder judiciário que o exerce seja concebido como um parceiro da democracia deliberativa. O modelo da

\footnotetext{
${ }^{97}$ Segundo Jacques LENOBLE: "Aux USA, cette transformation du droit sous couvert de sa nécessaire 'moralisation' a conduit à une profonde controverse (tant au sein de la communauté juridique qu'entre l'exécutif et la Cour Suprême) dès la fin du siècle passé. Cette lutte s'est résolue par une profonde transormation des mécanismes de régulation sociale et de la pensée juridique. La question en jeu était la légitimité de l'extension du domaine d'intervention des règles par rapport à l'automotive privée" (LENOBLE, op. cit., p. 97).

${ }^{98}$ Ver MICHELMAN, Frank. Brennan and Democracy. Princeton: Princenton University Press, 1999.

${ }^{99}$ Neste sentido, ver HABERMAS, Jürgen. Era das Transições. Rio de Janeiro: Tempo Brasileiro, 2003, p. 157.

${ }^{100}$ Cf. MICHELMAN, Brennan and Democracy, op. cit., p. 59.
} 
redistribuição do poder de Habermas pode auxiliar-nos nisso; podemos até ver a Corte Constitucional como um tipo de "representante formal do público"101.

\title{
Segundo Jürgen HABERMAS ${ }^{102}$,
}

Michelman certamente se apóia na intuição segundo a qual o assédio discursivo do tribunal através de uma sociedade mobilizada produz uma interação capaz de gerar conseqüências favoráveis para os dois lados, pois o alargamento da base de decisão faz com que o tribunal, que continua a decidir de modo independente, amplie também o campo de visão dos especialistas. E, aos olhos dos cidadãos que tentam influir no tribunal através de uma opinião pública provocativa, cresce a legitimidade do procedimento que conduz à decisão. Ora, a avaliação adequada das possíveis contribuições desse modelo para a solução do suposto paradoxo implica uma análise detalhada do papel cognitivo que o discurso impetuoso de um espaço público jurídico desempenha na prática de decisão do tribunal e o papel funcional que esta desempenha na aceitação social dos juízos. Temo, porém, que nas razões pragmáticas e circunstâncias históricas são muito mais decisivas, quando se trata de saber o modo como a tarefa de controlar as normas, num dado contexto, deve ser organizada. Como sabemos, tais possibilidades de institucionalização têm que ser avaliadas à luz dos princípios da soberania popular e do Estado de Direito, porém a constelação e o jogo desses princípios não propiciam soluções capazes de satisfazer a todos. Por isso, penso que, no âmbito de nosso questionamento, o caminho que Michelman escolheu para chegar ao seu modelo do juiz "que responde de modo responsável" é mais interessante do que a própria proposta ${ }^{103}$.

\section{Oliver GERSTENBER também critica a posição de MICHELMAN:}

\begin{abstract}
O que me surpreende nesses recentes artigos de Michelman é sua 'desconstrução' muito esclarecedora e sua reorganização dialética dos motivos do pensamento de Rawls, Habermas e Dworkin. Uma de suas principais contribuições é a de que um pluralismo razoável estende-se não a conceitos compreensivos de uma vida boa, mas também à esfera política (political real) das teorias constitucionais, obrigando-as a refletir sobre si mesmas. Um pluralismo razoável deve afetar nosso entendimento tanto sobre a autonomia da pessoa quanto sobre a autonomia política. O projeto democrático utópico torna-se, conseqüentemente, aquele que tenta realizar uma
\end{abstract}

${ }^{101}$ Frank MICHELMAN refere ainda que: "Ceci ne veut pas dire que nous évacuons le contrôle juridictionnel. Cela signifie plutôt que nous reconstruisons le contrôle jurisdictionnel d'une manière telle que le pouvoir judiciaire Qui l'exerce soit conçu comme un patrenaire de la démocratie déliberative. Le modèle habermassien de la redistribution du pouvoir peut nous y aider; nos pouvons même penser la Cour constitutionnelle comme un type de 'représentante formel du public'" (MICHELMAN, Frank. Le Juge et la Décision Politique. In: COPPENS, Philippe; LENOBLE, Jacques. Démocratie et Procéduralisation du Droit. Bruxelas: Bruylant Bruxeles, 2000, p. 80-81).

${ }^{102}$ Cf. HABERMAS, Era das Transições, op. cit., p. 158-159.

103 'C' 'est done à tort, relève enfin Habermas, que certains républicains américains, comme F. Michelman, croient devoir, dans ce supposé espace nouveau de liberté du juge ouvert par l'herméneutique constitucionnel des droits fondamentaux, investir le juge constitutionnel d'un rôle actif et d'un pouvoir que ne suffirait plus à penser le cadre limitatif traditionnel de la fonction de juger. Contrairement à ce que pose ce courant du républicanisme communautarien américain, le juge constitutionnel ne doit pas se concevoir comme un substitut du pouvoir du peuple à l'égard de la manière dont le pouvoir législatif exerce son povoir délibératif. Non seulement l'interprétation procédurale de la démocratie que ournit l'éthique de la discussion ainde à comprende le ondement du contrôle juridictionnel des droits fondamentaux. Mais en plus, cette interprétation permet de combien ce pouvoir, certes étendu, reste somis et enfermé dans les contraintes argumentatives qui définissent en dernier ressort la spécificité du jugement juridique (discours d'application) et as subordination au jugement du législateur (discours de justification)" (LENOBLE, op. cit., p. 107). 
"política transformativa" igualitarista "colocando os momentos fundadores numa época política contínua" e desbloqueando "a infindável interação entre os princípios da legalidade (...) e do auto-governo". Sinto-me fortemente atraído por este projeto e suponho que Michelman já pensou em certas questões e críticas às quais dedico a seqüência deste comentário. Minha tese principal é a de que, contrariamente a Michelman, acredito que o pluralismo razoável das interpretações constitucionais fornece um argumento a favor da procedimentalização (e não contra ela), que a procedimentalização e a integridade podem caminhar juntas e que a idéia nascente de um experimentalismo democrático oferece uma atraente perspectiva de reformas para as sociedades modernas. Meus dois pontos de discordância em relação a Michelman são os seguintes: (1) no que diz respeito às condições normativas da democracia, sua tese segundo a qual 'a democracia não pode decidir o que ela é "não me convence"; (2) em relação à possibilidade de realizar uma democracia deliberativa dentro das condições atuais, não acho convincente sua recusa total de valorização dos potenciais democráticos e das capacidades reflexivas inerentes à sociedade $^{104}$

$\mathrm{Na}$ interpretação liberal, o processo democrático de criação de leis legítimas exige determinada forma de institucionalização jurídica. A lei fundamental é introduzida como condição necessária e suficiente para o processo democrático, não como um resultado deste, pois a democracia não pode ser definida pela própria democracia.

Segundo Jürgen HABERMAS,

O fato de a constituição ser, de certo modo, inerente à democracia, pode ser tido como evidente por si mesmo. Mas o argumento apresentado não é suficiente para a fundamentação, porque se refere somente à parte da lei fundamental imediatamente constitutiva para a entronização da formação democrática da opinião e da vontade, ou seja, refere-se aos direitos políticos de participação e de comunicação. Ora, o núcleo dos direitos fundamentais é formado pelos clássicos direitos de liberdade: habeas corpus, o direito ao livre exercício da religião, direitos de propriedade; em síntese, todos os direitos de liberdade que garantem uma formação autônoma de vida e persecução do próprio bem-estar (pursuit of happiness). Esses direitos fundamentais liberais protegem, evidentemente, bens que possuem valor intrínseco.

104 “Ce Qui me surprend dans les articles récents de Michelman est as déconstrution très éclaire et son remaniement dialectique des motis de pensée de Rawls, Habermas et Dworkin. Un de ses principaux apports est qu'un pluralisme raisonnable s'etend non pas à des conceptions compréhensives de la vie bonne, mais aussi à la sphère politique (political realm) des théories constitutionelles et les orce à réléchir sur elles mêmes. Un pluralisme risonnable doit aecter notre compréhension tant le l'autonomie de la persone que de l'autonomie politique. Le projet démocratique utopique devient dès lors celui que tente de réaliser une politique transformative égalitarienne en plaçant les moments fondateurs dans une époque politique continue et en débloquant l'interaction sans fin entre les principles de la légalité (...) et de l'auto-gouvernement. Ce projet m'attire fortement et je suppose que Michelman a déjà songé à certaines questions et critiques auxquelles já consacre la suite de ce commentaire. Ma thèse principale est que, contrairemement à Michelman, je crois que le pluralisme raisonnable des interprétations constitutionnelles fournit un argument en aveurs de la procéduralisation (et non contre elle), que la procéduralisation et l'intégrité peuvent aller de pair et que l'idée naissante d'un expérimentalisme démocratique offre une perspective de réformes attrayante pour les sociétes modernes. Mês deux points de désacord par rapport à Michelman sont les suivants: 1) en ce qui concerne les contitions normatives de la démocratie, as thése selon laquelle 'la démocratie ne peut pas décider ce qu'elle est ne me convaint pas; 2). Par rapport à la possibilité de réaliser une démocratie délibertive dans le conditions contemporaines, je ne trouve pas convaincant son rejet comple de mise en valeur des potentiels démocratiques et des capacités rélexives inhérentes à la societé" (GERSTENBERG, Oliver. Démocratie Déliberative. In: COPPENS, Philippe; LENOBLE, Jacques. Démocratie et Procéduralisation $d u$ Droit. Bruxelas: Bruylant Bruxeles, 2000). 
Por isso, eles não se esgotam na função instrumental que podem vir a ter no exercício dos direitos políticos dos cidadãos. E, uma vez que as liberdades clássicas não têm sentido primário de promover a qualificação dos cidadãos, o fato de os direitos fundamentais liberais tornarem possível a democracia não basta para demonstrar que eles tornam viável a democracia - o que, no entanto, seria suficiente para os direitos fundamentais políticos ${ }^{105}$.

Uma Constituição que é democrática, não apenas de acordo com seu conteúdo, mas também de acordo com sua fonte de legitimação, constitui um projeto capaz de formar tradições com um início marcado na história ${ }^{106}$.

O conceito de Direito moderno - que intensifica e, ao mesmo tempo, operacionaliza a tensão entre faticidade e validade na área do comportamento - absorve o pensamento democrático, segundo o qual a pretensão de legitimidade de uma ordem jurídica construída com direitos subjetivos só pode ser resgatada através da força socialmente integradora da vontade unida e coincidente de todos os cidadãos livres e iguais ${ }^{107}$.

A partir do momento em que o Direito moderno é considerado como mecanismo que alivia as sobrecarregadas realizações de entendimento dos que agem comunicativamente de tarefas da integração social, sem anular, em princípio, a liberação do espaço da comunicação, tornam-se compreensíveis dois aspectos do direito: a positividade e a pretensão à aceitabilidade racional.

Ao se criar conscientemente uma estrutura de normas (positividade), surge um fragmento de realidade social produzida artificialmente, a qual só existe até segunda ordem, porque ela pode ser modificada ou colocada fora de ação em qualquer um de seus componentes singulares. Sob o aspecto da modificabilidade, a validade do direito positivo aparece como a expressão pura de uma vontade, a qual empresta duração a determinadas normas para que se oponham à possibilidade presente de virem a ser declaradas sem efeito. De outro lado, a positividade do direito não pode fundar-se somente na contingência de decisões arbitrárias, sem correr o risco de perder seu poder de integração social ${ }^{108}$.

O Direito extrai a sua força muito mais da aliança que a positividade do direito estabelece com a pretensão à legitimidade. Nessa ligação, reflete-se o entrelaçamento estrutural entre a aceitação, que fundamenta os fatos, e a aceitabilidade exigida por pretensões de validade, que já estava introduzida no agir comunicativo e na ordem social mais ou menos natural, na forma de tensão entre faticidade e validade. Essa tensão ideal retorna intensificada no nível do direito, mais precisamente na relação entre a coerção do direito, que garante um nível médio de aceitação da regra, e a idéia da autolegislação - ou da suposição da autonomia política dos cidadãos associados - que resgata a pretensão de legitimidade das próprias regras, ou seja, aquilo que as torna racionalmente aceitáveis ${ }^{109}$.

\footnotetext{
${ }^{105}$ Cf. HABERMAS, Era das Transições, op. cit., p. 159-160.

${ }^{106}$ Id., ibid., p. 165.

${ }^{107}$ Id., Direito e Democracia..., op. cit., p. 53.

${ }^{108}$ Id., ibid., p. 60.

${ }^{109}$ Id., ibid., p. 60.
} 
Essa tensão na dimensão de validade do direito implica a organização do poder político, empregado para impor legitimamente o direito (e o emprego autoritativo do direito); poder político ao qual o direito deve a sua positividade. A idéia do Estado de direito constitui uma resposta ao desiderato da transformação jurídica pressuposta pelo próprio direito.

Sociedades modernas são integradas não somente através de valores, normas e processos de entendimento, mas também sistemicamente, através de mercados e do poder administrativo. Dinheiro e poder administrativo constituem mecanismos de integração social, formadores de sistema, que coordenam as ações de forma objetiva. Ambos os meios ancoram-se nas ordens do mundo da vida, integrados na sociedade, através do agir comunicativo, seguindo o caminho da institucionalização do direito. Desta maneira, o direito está ligado às três fontes de integração social. Através de uma prática de autodeterminação, que exige dos cidadãos o exercício comum de suas liberdades comunicativas, o direito extrai sua força integradora, em última instância, de fontes de solidariedade social ${ }^{110}$.

Uma vez que o direito se interliga não somente com o poder administrativo e o dinheiro, mas também com a solidariedade, ele assimila, em suas realizações integradoras, imperativos de diferentes procedências ${ }^{111}$.

As leis coercitivas devem comprovar sua legitimidade como leis da liberdade no processo da legislação - e através do tipo de processo; e nessa positivação do direito, reproduz-se novamente a tensão entre faticidade e validade, porém não do mesmo modo que na dimensão da validade de normas legais. É permitido descrever o comportamento legal como uma obediência a normas que entraram em vigor, seja através da ameaça de sanções, seja através de um legislador político. No entanto, a faticidade da legislação distingue-se da implantação do direito que impõe sanções, na medida em que a permissão para a coerção jurídica é deduzida de uma expectativa de legitimidade associada à resolução do legislador (a qual poderia ser diferente e corrigível em princípio). A positividade do direito vem acompanhada da expectativa de que o processo democrático da legislação fundamente a suposição da aceitabilidade racional das normas estatuídas ${ }^{112}$.

Segundo Jürgen HABERMAS,

É necessário ir ainda mais longe e demonstrar como os princípios democráticos são inerentes à constituição da democracia enquanto tal. Para provar que a democracia e o Estado de direito não se encontram numa relação paradoxal, é necessário explicar em que sentido os direitos fundamentais na sua totalidade, portanto, não são apenas políticos dos cidadãos, são constitutivos para o processo da autolegislação. A teoria do discurso, do mesmo modo que as teorias precursoras no contrato social, simula um estado inicial que serve de ponto de partida: neste estado, pessoas em qualquer número resolvem entrar, por si mesmas, numa prática constituinte ${ }^{113}$.

\footnotetext{
${ }^{110}$ Id., ibid., p. 61-62.

111 Id., ibid., p. 62.

112 Id., ibid., p. 53-54.

${ }^{113}$ Id., Era das Transições, op. cit., p. 167-168.
} 
Na positividade do direito, não chega a se manifestar a faticidade de qualquer tipo contingente ou arbitrário da vontade e, sim, a vontade legítima, que resulta de uma autolegislação presumivelmente racional de cidadão politicamente autônomos ${ }^{114}$.

A autocompreensão normativa pode ser desmentida através de fatos sociais que intervêm no sistema jurídico a partir de fora. Aqui faticidade e validade encontram-se numa relação externa, pois ambos os momentos, o das implicações de sentido do direito vigente e o das limitações sociais, às quais as decisões jurídicas estão submetidas de fato, podem ser descritos isoladamente ${ }^{115}$.

Com o uso da linguagem orientada pelo entendimento, através do qual os atores coordenam suas ações (agir comunicativo), a relação de tensão entre validade e faticidade emigra para o mundo dos fatos sociais. Se antes era possível entender a faticidade dos eventos significativos e dos processos de fala como um momento necessário para a dimensão do significado e da validade, a partir de agora é necessário interpretar a tensão lingüística desencadeada no agir comunicativo através de pretensões de validade como um momento da faticidade social, a saber, da prática comunicativa cotidiana através da qual se reproduzem formas de vida.

As convicções compartilhadas intersubjetivamente formam o meio da integração social. Os atores estão convencidos acerca daquilo que entendem e têm como verdadeiro. Por isso, podemos ter duas atitudes frente a convicções que se tornam problemáticas: ou as apoiamos, lançando mão de argumentos, ou as rejeitamos ${ }^{116}$

Entretanto, os argumentos não são disposições para se ter opiniões que possam ser descritas naturalisticamente; eles constituem, ao invés disso, a garantia de uma troca discursiva, através da qual são resgatadas pretensões de validade criticáveis. Os argumentos devem sua força racionalmente motivadora a uma relação interna com a dimensão do significado e da validade de expressões lingüísticas. E constituem naturalmente uma faca de dois gumes, porque tanto podem fortalecer convicções, como estremecê-las. Com elas, a tensão entre faticidade e validade, que reside na linguagem e no seu uso, se introduz na sociedade. Sua integração social, na medida em que se apóia em convicções, é propensa ao efeito desestabilizador de argumentos desvalorizadores (especialmente quando há uma categoria inteira de argumentos). A tensão ideal que irrompe na realidade social remonta ao fato de que a aceitação de pretensões de validade, que cria fatos sociais e os perpetua, repousa sobre a aceitabilidade de razões dependentes de um contexto, que estão sempre expostas ao risco de serem desvalorizadas através de argumentos melhores e processos de aprendizagem que transformam o contexto ${ }^{117}$.

É certo que os argumentos só valem quando confrontados com standards de racionalidade dependentes de um contexto que funciona como pano de fundo; porém, argumentos que colocam em

\footnotetext{
${ }^{114}$ Id., Direito e Democracia..., op. cit., p. 54.

${ }^{115}$ Id., ibid., p. 55.

${ }^{116}$ Id., ibid., p. 56.

${ }^{117}$ Id., ibid., p. 57.
} 
evidência os resultados de processos de aprendizagem capazes de transformar o contexto também podem soterrar standards de racionalidade exercitados ${ }^{118}$.

No sentido de validade de convicções ligadas à autoridade, a faticidade e a validade se fundem. Na validade jurídica, ambos os momentos se separam um do outro: a aceitação da ordem jurídica é distinta da aceitabilidade dos argumentos sobre os quais ela apóia a sua pretensão de legitimidade. Essa dupla codificação remete, de outro lado, à circunstância de que a positividade e a pretensão à legitimidade do direito fazem jus à comunicação não circunscrita que expõe, em princípio, todas as normas e valores ao exame crítico ${ }^{119}$.

Os membros do direito têm que poder supor que eles mesmos, numa formação livre da opinião e da vontade política, autorizariam as regras às quais eles estão submetidos como destinatários. $\mathrm{Na}$ verdade, esse processo de legitimação torna-se um componente do sistema jurídico, uma vez que ele próprio necessita da institucionalização jurídica frente às contingências da comunicação do dia-a-dia, que flutua sem uma forma determinada. Sem prejuízo dessa limitação da comunicação, o risco constante da contradição é prolongado discursivamente e transformado na força produtiva de uma formação política, presumivelmente racional, da opinião e da vontade ${ }^{120}$.

Jacque LENOBLE ${ }^{121}$, ao abordar o pensamento de Jürgen HABERMAS, entende que uma das maiores dificuldades atuais de nossas democracias é a análise da transformação do papel do juiz. Segundo ele, a experiência jurídica dos debates abertos pelo controle dos direitos fundamentais mostra empiricamente que a vontade de Jürgen HABERMAS de encontrar um efetivo limite ao poder do juiz dentro da distinção justificar-aplicar revela-se ilusória. Como observaram os juristas americanos após o decreto Brown - que abre o que se poderia chamar de hermenêutica constitucional dos direitos fundamentais nos Estados Unidos - torna-se difícil encontrar, na imagem clássica da neutralidade do juiz, conforme sua submissão à regra, um critério de delimitação do poder do juiz.

\footnotetext{
${ }^{118}$ Id., ibid., p. 57-8.

${ }^{119}$ Id., ibid., p. 59-60.

${ }^{120}$ Id., ibid., p. 59-60.

${ }^{121}$ Jacques LENOBLE critica a posição de Jürgen HABERMAS com base nos seguintes argumentos: "En ce point se marque une des dificultés majeures aux quelles conduit cette manière de réléchir la transformation du rôle du juge dans nos démocraties. L'expérience juridique des débats ouverts par le contrôle des droits ondamentaux montre empiriquement que la volonté de Habermas de trouver une limite effective au pouvoir du juge dans la distinction justifier-appliquer s'avère illusoire. Non seulement, comme l'ont bien perçu les juristes américains après l'arrêt Brown quo ouvre ce qu'on pourrait appeler l'herméneutique constituonelle des droits fondamentaux aux USA, il devient dificile de trouver dans image classique de la neutralité du juge à raison de son inéodation à la régle un critére de délimitation du pouvoir du juge. Lorsque Habermas nous dit qu'il n'appartient pas au juge d'utiliser les droits ondamentaux pour inventer de nouveaux droits en lieu et place du législateur, sans doute a- t-il raison. Mais il est clir, comme le montre les débats jurisprudentiels et doctrinaux aux USA, qu'il n'est pas de critère formel clair pour opérer la limite du pouvoir d'interprétation. Ce n'est pas pour autant que le juge n'est pas guidé par des règles de raisonnement. Une herméneutique le guide qui oblige à poser que le juge ne décide pas n'importe comment n'importe quoi. Lá n'est pas le problème. Cela consiste à dire que la distinction logique qu'à juste titre Habermas pose entre la question de 1 valité ou de la pertinence d'une règle et celle de son application appropriée à un cas particulier ne permet pas, par ailleurs, de constituer une limite suffisante pour penser le rôle du juge" (LENOBLE, op. cit., p. 107-10).
} 
Quando Jürgen HABERMAS nos diz que não cabe ao juiz utilizar os direitos fundamentais para inventar novos direitos no lugar do legislador, sem dúvida, ele tem razão. Porém fica claro, como demonstram os debates jurisprudenciais e doutrinários nos Estados Unidos, que não há critério formal claro a ser aplicado ao limite do poder de interpretação. Não é por esta razão que o juiz não segue as regras do raciocínio. Ele é guiado por uma hermenêutica que obriga a colocar que o juiz não decide de qualquer maneira qualquer coisa.

O problema não reside aqui. Isto consiste em dizer que a distinção lógica que Jürgen HABERMAS faz, com razão, entre a questão da validade ou da pertinência de uma regra e a de sua aplicação adequada a um caso particular, não permite, por outro lado, constituir um limite suficiente para refletir sobre o papel do juiz. Ao lado da abertura hermenêutica que caracteriza este problema demasiadamente acentuado da interpretação no Direito, ao lado das distinções induzidas pela lógica da argumentação lembradas por Jürgen HABERMAS, o discurso de aplicação é guiado por uma terceira dificuldade lógica, sempre obliterada e ignorada: as dificuldades lógicas ligadas à conscientização da necessária transformação dos contextos de segundo plano que se impõem, se quisermos assegurar a eficiência da regra.

\section{REFERÊNCIAS BIBLIOGRÁFICAS}

ARAGÃO, Lúcia Maria de Carvalho. Razão comunicativa e Teoria social crítica em Jürgen Habermas. Rio de Janeiro: Tempo Brasileiro, 1997.

ARNAUD, André-Jean; DULCE, María José Fariñas. Introdução à Análise Sociológica dos Sistemas Jurídicos. Rio de Janeiro: Renovar, 2000.

AUSTIN, John L. Cómo hacer cosas con palabras. Barcelona: Paidós, 1998.

CANON, Bradley C.; JOHNSON, Charles A. Judicial Policies. 2. ed. Washington: CQ Press, 1999.

CARRIÓ, Genaro. Algunas palavras sobre las palavras de la ley. Buenos Aires: Abeledo Perrot, 1971.

CARRIÓ, Genaro. Notas sobre Derecho y lenguage. 4. ed. Buenos Aires: Albeledo-Perrot, 1990.

COSTA, Regenaldo da. Discurso, Direito e Democracia em Habermas. In: MOREIRA, Luiz. Direito e Legitimidade. São Paulo: Landy, 2003.

DURKHEIM, Émile. A Divisão do Trabalho Social. 2. ed. São Paulo: Martins Fontes, 1999.

GERSTENBERG, Oliver. Démocratie Déliberative. In: COPPENS, Philippe; LENOBLE, Jacques (Eds.). Démocratie et Procéduralisation du Droit. Bruxelas: Bruylant Bruxeles, 2000.

GRANA, Sheryl J. et al. The social context of law. 2. ed. New Jersey: Prentice Hall, 2002.

GRONDIN, Jean. Introdução à Hermenêutica Filosófica. São Leopoldo: Unisinos, 1999.

HABERMAS, Jürgen. Between facts and norms - contributions to a discourse theory of law and democracy. Cambridge: Mit Press, 1996. 
HABERMAS, Jürgen. Direito e Democracia - entre facticidade e validade. Rio de Janeiro: Tempo Brasileiro, 1997. v. I.

HABERMAS, Jürgen. Era das Transições. Rio de Janeiro: Tempo Brasileiro, 2003.

HABERMAS, Jürgen. La Logica de las Ciencias Sociales. Madrid: Tecnos, 1988.

HABERMAS, Jürgen. O Discurso Filosófico da Modernidade. Uma outra via para sair da filosofia do sujeito - Razão comunicativa vs. Razão centrada no sujeito. São Paulo: Martins Fontes, 2002.

HABERMAS, Jürgen. Sobre a legitimação pelos direitos humanos. In: MOREIRA, Luiz. Direito $e$ Legitimidade. São Paulo: Landy, 2003.

HABERMAS, Jürgen. The Theory of Communicative Action. Boston: Beacon Press, 1984. v. I.

HEATH, Joseph. Communicative Action and Rational Choice. Cambridge: Mit Press, 2001.

HORWITZ, Morton J. The Transformation of American Law 1870 - 1960 - The Crisis of Legal Orthodoxy. New York: Oxford University Press, 1992.

KERVÉGAN, Jean-François. Democracia e Direitos Humanos. In: MOREIRA, Luiz. Direito e Legitimidade. São Paulo: Landy, 2003.

KOZICKI Kátia. Conflito e Estabilização: comprometendo radicalmente a aplicação do Direito com a democracia nas sociedades contemporâneas. Tese de Doutorado em Direito, Universidade Federal de Santa Catarina, 2000.

LEFORT, Claude. La invención democrática. Buenos Aires: Nueva Visión, 1988.

LENOBLE, Jacques. La Procéduralisation Contextuelle du Droit. In: COPPENS, Philippe; LENOBLE, Jacques. Démocratie et Procéduralisation du Droit. Bruxelas: Bruylant Bruxeles, 2000.

LUHMANN, Niklas. Differenziazione del Sistema Giuridico - Contributi alla sociologia e alla teoria del diritto. Bologna: Il Mulino, 1990.

MACINTYRE Alasdair. Justiça de quem? Qual Racionalidade? São Paulo: Loyola, 1991.

MARRADES MILLET, Julián. Gramática y naturaleza humana. In: VIDARTE, Vicente Sanfélix (Coord.). Acerca de Wittgenstein. Valencia: Universidad de Valencia, 1993. p. 97-112.

MATTOS, Patrícia Castro. As visões de Weber e Habermas sobre Direito e Política. Porto Alegre: $\mathrm{SaFe}, 2002$.

MERTON, R. Social. Sociologia - Teoria e Estrutura. São Paulo: Mestre Jou, 1968.

MICHELMAN, Frank. Le Juge et la Décision Politique. In: COPPENS, Philippe; LENOBLE, Jacques (Eds.). Démocratie et Procéduralisation du Droit. Bruxelas: Bruylant Bruxeles, 2000.

MICHELMAN, Frank. Brennan and Democracy. Princeton: Princenton University Press, 1999.

MOREIRA, Luiz. Direito e Normatividade. In: MOREIRA, Luiz. Direito e Legitimidade. São Paulo: Landy, 2003.

MOUFFE, Chantal. Dimensions of radical democracy. London: Verso, 1992.

NOWAK , John E.; ROTUNDA, Ronald D. Constitutional Law. 5. ed. St Paul: West Publishing, 1995. 
OLIVEIRA, Ana Claudia de; LANDOWSKI, Eric (Eds.). Do inteligivel ao sensivel - Em torno da obra de Algirdas Julien Greimas. São Paulo: EDUC, 1995.

ORWELL, George. 1984. São Paulo: Companhia Editora Nacional, 2003.

PARSONS Talcott. El Sistema de las Sociedades Modernas. México: Trillas, 1974.

PERRY Jr., H. W. Deciding to decide - Agenda Setting in the United States Supreme Court. Cambridge/London, 1991.

PITKIN, Hanna Fenichel. Wittgenstein: El lenguage, la politica y la justicia - Sobre el significado de Ludwig Wittgenstein para el pensamiento social y político. Madrid: Centro de Estudios Constitucionales, 1984.

RAWLS, John. A theory of justice. Cambridge: Harvard University Press, 1972.

RICHARDSON, Henry. Em defesa de uma democracia qualificada. In: MOREIRA, Luiz. Direito e Legitimidade. São Paulo: Landy, 2003.

ROCHA, Leonel Severo. A Teoria Jurídica no Final do Século: Forma de sociedade, cultura política e democracia. Revista Brasileira de Filosofia, v. XLI, Fasc. 172, p. 365-78, out./dez. 1993.

ROCHA, Leonel Severo. Epistemologia jurídica e democracia. São Leopoldo: Unisinos, 1998.

RORTY, Richard. El giro lingüístico. Barcelona: Paidós Ibérica, 1998.

ROSENBERG, Gerald N. The Hollow hope - Can Courts bring about social change? Chicago/London: University of Chicago, 1991.

SANTOS, Boaventura de Souza. Reinventar a Democracia. 2. ed. Lisboa: Gradiva, 2002.

SCALA, Antonin et al. A Matter of Interpretation - Federal Courts and the Law. Princeton: Princeton University Press, 1997.

SHUMPETER, Joseph A. Capitalism, socialism \& democracy. London: Routledge, 1996.

SIEBENEICHLER, Flávio Beno. Jürgen Habermas - Razão comunicativa e Emancipação. 2. ed. Rio de Janeiro: Tempo Brasileiro, 1990.

STIEL TJES, Cláudio. Jürgen Habermas-A desconstrução de uma teoria. Jabaquara: Germinal, 2001.

TOCQUEVILLE, Alexis. A Democracia na América. São Paulo: Martins Fontes, 2001.

TRIBE, Laurence H. American Constitucional Law. 3. ed. New York: Fondation Press, 2000. v. 1.

TRIBE, Laurence H.; DORE, Michel C. On reading the Constitution. Cambridge/London: Harvard University Press, 1991.

VAZ, Henrique Cláudio de Lima. Ética, direito e justiça. In: MOREIRA, Luiz. Direito e Legitimidade. São Paulo: Landy, 2003.

WARAT, Luís Alberto. Introdução geral ao direito. Porto Alegre: Safe, 1995. v. 3.

WHITE, Stephen K. The recent work of Jürgen Habermas - Reason, justice \& modernity. New York: Cambridge University Press, 1988. 